Thematic Issue - Modelling with Stakeholders http://dx.doi.org/10.1016/..envsoft.2009.10.010 (c) 2009 Elsevier Ltd All rights reserved.

\title{
A co-modelling process of social and natural dynamics on the isle of Ouessant: Sheep, turf and bikes
}

\author{
Mathias Rouan ${ }^{a,}{ }^{*}$, Christian Kerbiriou $^{b}$, Harold Levrel $^{\mathrm{c}}$ and Michel Etienne ${ }^{\mathrm{d}}$ \\ a LETG-Géomer UMR6554 CNRS, Institut Universitaire Européen de la Mer, place Copernic, 29280 Plouzané, \\ France \\ ${ }^{\mathrm{b}}$ CERSP, Muséum National d'Histoire Naturelle, 55 rue Buffon, 75005 Paris, France \\ c IFREMER, UMR AMURE, Département d'Economie Maritime, BP70, 29280 Plouzané, France \\ ${ }^{d}$ Ecodevelopment Unit, INRA, Site Agroparc, 84914 Avignon cedex 9, France \\ *: Corresponding author : M. Rouan, Fax: +33 298 498703, email address : mathias.rouan@univ-brest.fr
}

\begin{abstract}
:
An interdisciplinary team has applied the multi-agent system formalism to study shrub encroachment in the Biosphere Reserve on the isle of Ouessant. The main goals were (1) to understand vegetation dynamics, and (2) to represent how main agents, or actors view the dynamics of natural resources in relation to their own living practices. The management strategies established for each type of stakeholders were formalised and the impact of these strategies on biodiversity was analyzed at various temporal and spatial scales. Following a short description of the model, three aspects of the modelling process are discussed in more detail: the use of the chough (Pyrrhocorax pyrrhocorax) population as a representative variable for the interactions between stakeholders and territory, the use of non-monetary economic indicators, and the ways that multi-disciplinary scientific knowledge can be integrated into the model.
\end{abstract}

Keywords: Companion modelling; Agent-based model; Biodiversity; Social dynamics; Shrub encroachment; Biosphere Reserve 


\section{Introduction}

Nowadays modern agriculture should be regarded as a major anthropogenic threat to biodiversity and social structure, comparable to global climate change in its ability to affect vast areas (Fuller et al., 1995; Siriwardena et al., 1998; Maes and Dyck, 2001; Krebs, 1999; Tilman et al., 2001). The current major trends in European agriculture are characterised, on the one hand, by an intensification process that shows in, for example, transformation of dry grassland into fast-growing crops through irrigation, or increase of fertiliser and pesticide application; and on the other hand, by a shift to more environmentally friendly practices. However, on the European scale of change, agriculture is declining as an indirect result of intensification because marginal lands become less profitable to farm and traditional more labour intensive agricultural practices are displaced by more cost effective practices. While there is agreement about the negative impact of agricultural intensification on biodiversity, there is however no consensus on how shrub encroachment affects biodiversity. When intensive agricultural land is abandoned, it can become a source of biodiversity (Grossi et al., 1995), whereas when shrubs occupy low-intensity land with high biodiversity, it is often perceived as a loss of biodiversity (Diáz et al., 1997; MacDonald et al., 2000; Franco and Sutherland, 2004). This is especially the case in isolated ecosystems such as small islands where agriculture becomes inefficient and is replaced by a tourism-based economy (Di Castri and Balaji, 2002). At the same time, tourism can also impact biodiversity. These synergistic impacts on biodiversity are poorly studied and require a detailed integrative analysis, involving innovative interdisciplinary work and use of new dynamic tools (Etienne et al., 2003; Levrel et al., 2009a). This study was carried out within the framework of a project on "Organisation of access to resources and biodiversity applied to the French Biosphere Reserves (BR)", funded by the French Institute for 
Biodiversity. It aimed at modelling interactions between natural and social dynamics within the theoretical framework of multi-agent modelling. In this project, the stakeholders involved with natural areas of heritage or environmental interest put forward their concern for possible changes in environmental dynamics. The main goals were to understand the future environmental dynamics and to represent the main actors' view on natural resources and their dynamics in the context of their own objectives and according to their own, individual criteria. The management strategies established for each type of stakeholders were then formalised and the impact of these strategies on biodiversity was measured at various temporal and spatial scales. Within the framework of the project, the Companion Modelling approach (Commod, 2006) was used for the study of four French Biosphere Reserves (Vosges du Nord, Lubéron, Ventoux and Mer d'Iroise). In this paper, we present the model developed for the isle of Ouessant, to give an example of an application of this integrative methodology and the analysis that it helped to perform.

\section{Study area, context, driving force and data}

Ouessant is a small island (1,541 ha) located $20 \mathrm{~km}$ west off the western coast of Brittany, France $\left(48^{\circ} 28^{\prime} \mathrm{N}, 5^{\circ} 5^{\prime} \mathrm{W}\right)$. The isle is currently in a period of rapid socio-ecological change. Social change is characterised by decrease in the island's native population and a great increase in the number of tourists.

\section{Native human population:}

At the beginning of the $20^{\text {th }}$ century, the population of the island was 2,661 ; one century later, there are now 956 people. Moreover, the demographic structure of the isle of Ouessant shows that the 65+ year-old age group is predominant: it is approximately 400 people - i.e., nearly $50 \%$ of the population (data from the national population census, INSEE 2008).

\section{Agricultural practices:}

In the middle of the 1950s, Ouessant crop farming started to disappear, and a drastic decrease in livestock occurred (sheep, the main livestock, decreased from 4,500 in 1950 to 650 in 2003 [Rattier, 2005]). Sheep breeding is a traditional practice, yet in 2000 a new practice emerged: cattle breeding, which entailed land clearing operations.

\section{Land use changes:}

Land use changes can be tracked using the aerial photography of the island available for 1952, 1982, 1992, and 2000. Combining livestock data with information about pasture land and shrub encroachment over the same periods show that, after the 1950s, grazing could no longer maintain perennial herbaceous vegetation (Levrel et al., 2009b). The shrub encroachment resulted in bramble, bracken, gorse and willow colonisation, their coverage rising from less than $1 \%$ in 1952 to $43 \%$ of the island area in 1992 (Gourmelon et al., 1995).

\section{Tourist visitation:}

Over the last fifty years, the number of visitors has increased dramatically because of growing interest in wilderness areas and, in addition, due to market liberalisation (until 1990 passenger transport was under public ownership) that increased the capacity of passenger transport (Levrel et al., 2009b). The annual number of ferry passengers (based on companies' archives and tourist offices) grew from 5,000 in 1950 to 150,000 in 2005 (Kerbiriou et al., 2008). Tourists trample on coastal vegetation and disturb the fauna. Another impact of tourism comes from second homes. This trend is not new on the isle of Ouessant since there were already 235 of such homes as far back as 1915. In 1990, the number of second homes has reached 360, which shows that the increase is slow, yet steady. Because of building restrictions, second homes compete with permanent housing. This affects sheep breeding, by pushing permanent residents out. Furthermore, an ethno-sociological study revealed 3 main categories of residents in terms of their perception of shrub encroachment, livestock breeding and turf collection. (Bellec, 2005).

\section{Nature heritage:}


Due to the presence of rare species, high biological diversity and an exceptionally preserved coastal ecosystem, the island is listed in national and European inventories such as the International Bird Area and NATURA 2000. Ouessant is part of a Natural Regional Park since 1969, and became a Man and Biosphere Reserve in 1988. Almost all rare terrestrial species and habitats under protection are located in a narrow strip along the coast (Kerbiriou et al., 2008). Ecological change is mainly due to shrub encroachment and the development of tourism.

Biodiversity and nature heritage are represented in our agent-based model (ABM) by the chough (Pyrrhocorax pyrrhocorax) population dynamics. This bird is a rare species (listed in Annex 1 of the European Union Directive 79/409/EEC on the Conservation of Wild Birds) and is considered an indicator species, because it forages in coastal habitats where rare and protected plants grow (Kerbiriou, 2006; Kerbiriou et al., 2008). Furthermore, this species is sensitive to the two main socioecological changes: tourist trampling and shrub encroachment affect its foraging habitat and tourist disturbance affects the survival of the young (Kerbiriou et al., 2006b; 2009).

Driving force

The shrub encroachment and tourist activities led to changes in land use on the isle and mostly impacted the coastal areas located on the edges of cliffs (footpaths, cycle trails, turf cropping for the making of a traditional dish in local restaurants). Besides, grazing in proximity of houses restricted collective use of free-range pastures (Gourmelon et al., 2001).

Given this context, the aim of the research was to provide managers and local authorities with a sound scientific database and a decision support tool to improve planning of access to this coastal fringe for both recreational use and production.

\section{Methodology}

\subsection{Background}

In 2001, a first spatial modelling approach using GIS led to the drafting of environmental evolution scenarios according to sheep grazing patterns in 1992 (Gourmelon et al., 2001; Gourmelon, 2003). The scenarios were based on three parameters: environmental typology (vegetation) and sheep distribution in 1992, pasture concentration in proximity of dwellings, and the threshold of 2-3 sheep/ha accepted as the stocking rate required to maintain the environment as it was. On this basis, four different scenarios were imagined: (1) the complete disappearance of sheep; (2) the sheep population dwindling to 700; (3) a "neutral" scenario based on the state of the sheep population in 1992 (approx. 1,000 sheep); (4) the sheep population increasing to 1,400 (Figure 1). All these scenarios led to interesting yet debatable results. Moreover, the underlying hypotheses of these results were excessively theoretical, since they did not include the changes in maintenance practices by the islanders, nor a number of other parameters such as, for example, the recent introduction of new types of livestock farming. To overcome these insufficiencies and in order to provide a modelling method supplying managers with a useful tool, the multi-agent modelling approach was suggested as a potentially successful second generation modelling strategy. This approach took into account human activity issues and included, to some extent, temporal variability. The behaviour of various agents was established, changing over the course of time as they adapted to environmental changes (e.g. territory). Furthermore, this approach included stakeholders' by modelling, for instance, their decision-making methods: how they became aware of a problem, what source of information they used, etc. MultiAgent systems are widely used to modelling complex systems in environmental studies (Athanasiadis, 2009), and particularly on land-use changes (Bithell and Brasington, 2009; Moreno 2007).

\subsection{The multi-disciplinary network}

We followed step by step the phases (Figure 2) defined by the ARDI method : Actors, Resources, Dynamics and Interactions (Etienne, 2006). The team included experts in natural sciences (ecologist, ornithologist, and plant ecologist), experts in social sciences (ethnologist and economist), an expert in Geographical Information Systems (GIS), the manager and a modeller. Most members of this team had already been involved in and completed scientific studies on different aspects of the isle of Ouessant, providing a number of facts on various topics (Gourmelon et al., 1995; 2001). Yet, the modelling process highlighted the lack of data in several fields such as stakeholder perception of 
system dynamics, and stakeholder selection criteria. As a result, specific surveys were launched, with the aim to collect quantitative data (areas of turf-digging, areas used by sheep flocks, etc.). They were also an opportunity to discuss practices with stakeholders and inform them about the project.

\subsection{Agent-Based Model description}

Spatial and temporal scale

The agent-based model (ABM) (Ferber, 1995) described hereafter was developed on the basis of the CORMAS modelling platform (Bousquet, 1998), developed by CIRAD. CORMAS is a French equivalent of SWARM (Minar et al., 1996): a multi-agent software platform for the simulation of complex adaptive systems. It provides object-oriented libraries of reusable components for building, analysing, displaying and testing models. Unlike SWARM, CORMAS is dedicated to Natural Resources Management issues. It provides generic features to create and manipulate aggregate spatial entities used as specific management units by different types of stakeholders.

In our model, the environment was represented by a genuine map of the island imported in raster mode into the cellular automaton of the CORMAS platform.

The basic entity of the automaton was the cell, with its specific properties such as "knowing" its immediate proximity, the aggregate spatial entities comprising it and the hosted agents. One of the essential phases of the process involved choosing the appropriate resolution for the spatial modelling of the territory. A $200 \mathrm{~m}^{2}$ resolution was selected as an appropriate compromise between accuracy and computational efficiency of the model. In addition to the CORMAS standard cellular automaton attributes (id, neighbourhood, occupants, etc..) we created 20 extra attributes, 13 of which came from the GIS and were therefore available as soon as the map was initialised. Table 1 shows the meaning of each attribute and how each one was updated in the model.

After establishing the spatial resolution, we also had to choose the temporal step for the model, i.e., the amount of time represented by a simulation step, or the minimum amount of time between two different states of the model we wanted to represent. The year was divided into the three periods that seemed relevant in terms of both natural and social time periods on the isle of Ouessant (Table 2): February to May, June to September and October to January.

\section{Structure of the socio-ecological model}

The conceptual model was co-constructed by the multi-disciplinary team in accordance with the ARDI method (Etienne, 2009), and developed collectively by successively identifying the actors, the resources, the dynamic processes and the interactions between nature and society most relevant to the project. Three workshops were held between the completion of the first draft model (Figure 3) completed in December 2003, in which the main actors (breeder, chough, visitor, flock...) and the key interactions with the different resources were identified, and the final version (Figure 4). The model was improved and validated at each phase, and the decision to drop or add various entities was discussed and justified at great length. We detected two types of agents, some indirect actors that had no direct impact on the core process of the model (shrub encroachment) but whose decisions affected, in some cases, direct stakeholders' practices. This is especially the case of restaurateurs who, in order to cook traditional stew for tourists, order a stock of grass turfs previously harvested from the coastal fringe by a turf collector. Direct actors, like sheep or cattle farmers, have a direct impact on shrub encroachment.

In figure 4, the elements in light grey represent unimplemented parts of the conceptual model. In the final model, management entities were reduced to the different values of the cell's "typeVeg" attribute whereas, in the initial model, they were aggregated into more heterogeneous units (pasture, coastal fringe...). The reason for this was the multiplication of management entities belonging to each agent, during the modelling process and the prototype's implementation. Although some agents and dynamics were simplified because they finally did not require the expected level of detail, others were refined to better reflect the dynamics. These model evolutions took place as a result of the fieldwork and stakeholder investigations.

The core of the model consists of the vegetation dynamics as represented in the state and transition diagram (Figure 5). The two parts clearly defined refer to two distinctive territories on the island, whose vegetation succession series were divided in the model. On one side, coastal vegetation adapted 
to harsh conditions (wind, sea spray, shallow soil) on exposed cliffs with land use pressure essentially linked to the development of tourism (trampling and turf collection); on the other side, inland vegetation largely occupied by natural mesophilic grasslands with maintenance practices being operated due to sheep grazing in decline.

The agents

The Ouessant model included 12 agents as identified in bold in the text below.

Tourism and the constantly increasing number of visitors in search of peace, quiet and nature on the isle of Ouessant encouraged restaurateurs to revive a traditional island dish known as "ragout sous la motte" (stew under turf!). In this recipe, the casserole is covered with coastal grass turfs, which are ignited and burn slowly, releasing a mutton stew aroma. The turfs are literally cut out of the meadows and the moors of the island's coastal fringe by turf collectors equipped with supposedly traditional tools, and they are dried on low walls or in the so-called "crèches". Currently, five turf collectors dig 1,500 to 7,500 grass turfs per year, which covers a small area altogether but, according to their location and aspect, these areas are important for the visitors' visual perception of the landscape. There are four different types of livestock farming on the isle of Ouessant, each one with its own island-specific features. The only cattle-breeding farmer has permanent pens and also a mobile pen that he moves around according to the bans implemented by CEMO (Centre d'Etude $d u$ Milieu d'Ouessant) or when a conflict arises with second home owners in the neighbourhood, objecting to the proximity of cows (Levrel, 2004; Bellec, 2005). When a conflict occurs near the coast, these house owners usually complain to the council by approaching the local representatives, who in turn put pressure on $\boldsymbol{C E M O}$ by means of the Regional Park (PNRA, Parc Naturel Régional d'Armorique). The only horse breeder is confined to a few plots of land in the middle of the island near the village of Lampaul. The impact of his activity on shrub encroachment is minimal (Figure 6). Most of the livestock farmers on the island are sheep breeders using traditional grazing stick practices. The sheep are moved twice a day to the swards near the farmers' homes. These swards are also mowed by the farmers or by professional mowers (Gourié, 2004). In order to stop shrubs from encroaching extensively on their grazing areas, some farmers have a few goats, which they place in the outer zones of their sward area where they browse woody vegetation. A community of goat breeders has thus developed in recent years and a collective goat flock is now forming during the free-range grazing period, which was so far reserved for sheep flocks. The recent appearance of goats on the island is not unanimously supported. The goat flock is restricted to one corner of the island and is alternatively guarded by the different members of the goat association. On the other hand, sheep flocks roam freely during this 4-month period and are commonly seen wandering on the roads or near the cliffs (Rattier, 2005), where their grazing could contribute to maintaining chough populations.

\section{Scenarios of potential social changes}

In order to focus on a limited number of scenarios, we chose the most probable trends for each dynamics identified as well as specific scenarios linked to specific stakeholder requests.

\section{Human population trend}

Current evolution trends of the Ouessant society (see methods section) were used as a basis for the construction of this scenario. The constant decline in the local population was modelled accounting for the demographic structure in all scenarios.

\section{Livestock trend}

Grazing pressure changes are directly linked to local population trends. The decrease in cattle stock at the end of the $19^{\text {th }}$ century, and in sheep stock since 1950 to the present, is therefore directly related to shrub encroachment throughout this period (Figure 6). The establishment of a modern cattle farmer in the 1990s may reverse this trend. However, as this activity rests on only one breeder, various ways of evolution can be predicted. Currently, this activity is barely cost-effective (as there is no slaughterhouse on the island, carcasses have to be sent to the mainland), and the cattle breeder is planning to retire in the next ten years (Levrel, 2004). This constitutes a first option in the scenario, but an alternative could be that the cattle farm is taken over by a young breeder. 


\section{Tourist trend}

The last trend is related to tourist visitation which, after increasing consistently for several decades, may have reached a stable level, probably due to the restricted amount of available island accommodation and restricted transportation services to and from the island. Therefore, among the range of tourist dynamics possibilities, we used visitation data stabilised at the current level.

\section{Results and discussion}

Following the implementation of this scenario, approximately thirty simulations were launched using the year 2002 as a reference state (initial parameters are defined in Table 3) and a time horizon of 15 years, in order to measure the variability of observed results. Figure 7 shows the results of the analysis of simulation variability using a mean stabilising method. Indeed, because of the random proportion in the model, a certain number of simulations had to be carried out in order to consider the results' mean as being stable. Moreover, as the accuracy of the resolution and the large number of agents were costly in terms of calculation time (approx. 3 hours/simulation), we had to seek a balance between the minimum number of simulations required to obtain a satisfactory result and a reasonable calculation time. With an average of thirty simulations, the mean ranged within a $5 \%$ confidence interval (calculated from the mean of 100 simulations).

The results presented in figure 8 show the vegetation state in 2002 and the results of a simulation 15 years later (dark colours distinguish shrub-encroached areas). The mean evolution of the "number of choughs" may also be observed, highlighting the gradual disappearance of the chough population on the island in the case of this scenario.

In this section of the paper, we detail three modelling specificities:

- we attempt to split dynamics into fewer simple dynamics through an interdisciplinary approach to companion modelling, in order to divide the overall process;

- we then evaluate the advantage of modelling chough population dynamics using interacting agents' properties;

- we finally focus on socio-economic dynamics modelling, detailing the approach (none of the agents based their decisions on costs, traditional economics indicator).

\subsection{An interdisciplinary approach to companion modelling}

The role of scientific knowledge in constructing the model varies according to the intensity of the partnership sought during the companion modelling process (Commod, 2006). In the case of the work carried out in the Iroise Biosphere Reserve, the group included experts in vegetation dynamics, a bird expert for the indicator species, and researchers in social sciences able to provide a scientific view on the practices and perceptions of the stakeholders (ethnologist), or on the access to resources and the conservation of biodiversity (economist). The facilitator decided to select scientists who had knowledge of the various analyses at stake. Some were present from the start of the project. Others, such as the ornithologist, were included when the group was working on the dynamics or the interactions, and particular expertise was required for the good understanding of the process. This latter aspect seemed worth developing since the originality of the model resided in the approach and the way it stimulated exchanges between the different disciplines. The facilitator was in charge of the quality, intensity and effectiveness of these exchanges at the four following key moments of the modelling process.

\section{Co-constructing a shared representation}

During the numerous co-construction workshops, the facilitator simply made sure that everyone got a chance to speak and took standardised notes of the disciplinary experts' proposals. The only time he took part in the debate was to reformulate proposals deemed excessively generic or when a polysemous or confusing word was used. For example, in the first case, the term "inhabitant" was eventually rejected because the discussion showed that it included stakeholders at large, which had previously been identified in the model (livestock breeders, restaurateurs, etc.). It was agreed that the inhabitants who had nothing to do with these activities should be identified and included under the term "secondary residents". In the second case, the terms referring to the vegetation state (pasture, 
lawn, shrub, moor, or thicket) rapidly needed to be clarified. The term "pâturage" (pasture, in French) was rejected because it could equally mean the place where sheep graze and the act of grazing. And naturally, grassland (resource providing fodder) is not necessarily used for grazing (farmers do not necessarily place their sheep there).

At the end of this co-construction phase, the facilitator summed up the diagrams produced and encouraged the group to identify weaknesses. Potentially, three types of weaknesses needed to be identified. 1) An activity or a resource was identified as a predominant or arising problem but none of the participants felt they were in a position to give a well-informed view on the matter. The group then decided to call on an expert to draw up a report. In this case, a group member was assigned to the job of finding and mobilising the appropriate expert. 2) A key actor was forgotten in the preparatory phase and this absence had an impact on the group. The person to be summoned for the next phase was agreed upon. 3) An actor, a resource or a dynamics process caused a disagreement between two or several participants in the approach. The group decided on the best way to end this disagreement and on the type of information that needed to be gathered to end the deadlock.

\section{Identifying weaknesses}

Identifying weaknesses was particularly efficient in the construction of the interactions diagram. Each participant in turn placed a new resource or a new actor in the diagram then identified or explained an interaction occurring between an actor and a resource or between two actors. Each newly proposed interaction was determined by an arrow and a verb specifying the type of action that generated it. The introducer had to justify his/her choice and indicate, if possible, the type of information used by the actors to make the corresponding decision (e.g., I round up my flock because it is the first Wednesday of February, the traditional end date of free-range grazing). If another scientist had a different view, they argued in order to reach a mutual agreement.

The facilitator's role was particularly tricky in this phase since he had to construct a clear diagram (avoiding arrows in all directions). He had to ask the participants to explain their choices (and at the same time avoid putting them in a difficult situation), and he had to reopen the discussion on issues for which there were no arrows (without actually pressing the participants). In fact, the facilitating process had three main objectives: 1) to gradually draft a diagram understood by all, 2) to identify clear and undeniable interactions, and 3) to make up for points that had been forgotten, and identify lacks or doubts. Moreover, special efforts were needed to get the participants to reformulate their proposals to avoid using verbs insufficiently informative (e.g., the flock grazes; the farmer cultivates his field; the mayor manages his budget) or to only use meaningful interactions connected to the question (e.g., in tourist management, meaningful interactions include the path used by the tourists and the demand for stew; the rest of the itinerary is of no interest).

\section{Questioning the value of knowledge}

In elaborating the Ouessant model, interactions between two resources led to questioning the participants' knowledge, either because there were gaps in the information they gave or because a viewpoint in one science field could be complemented by another.

Turf is collected on coastal meadows, with earth trapped in the root hairs. This activity was the subject of the first debate. In order to meet the increasing demand from tourists, turf collecting intensified and modernised but it raises questions in terms of the preservation of this unusual coastal fringe habitat. The importance of coastal meadows in the feeding of red-billed chough chicks is a well-known fact, but the connection between the resource and its direct and indirect users required further research. The "tradition" developed by Ouessant women of cultivating their fields and cooking their mutton stew indeed no longer applies because demand is nowadays seasonal and changeable, and turf collecting has become an increasingly professionalised activity. The group therefore decided to study the changes occurring in turf collection (comparative study of the former and new method), the emergence of a turf market (i.e., cash income, paid activity), and to measure the impact of current practices on vegetation both in terms of regeneration capacity and landscape perception. This work was carried out by analysing local and scientific knowledge, with the aim of producing accurate cost-related data to assess the potential damage and extent of the existing activity. 
The second debate was dedicated to formalising grazing activities. The main difficulty was to check if the available information on sheep grazing was also valid for other types of livestock breeding currently developing on the island (cattle, goats and horses) and if its accuracy matched the objectives of the model. The cross viewpoints of biological and social sciences encouraged a joint study on livestock farming strategies and the impact of livestock grazing or browsing on shrub encroachment dynamics. The importance of tradition in livestock farming and the cultural image of sheep on the isle of Ouessant justified maintaining free-range grazing and grazing stick practices. Other livestock farmers tending towards economic (cattle, horses) or land management (goats) strategies aimed at efficiency. Our research highlighted the difficulty to measure grazing pressure accurately since the animals are left free to roam for part of the year (free-range grazing), and may be associated with other animals (sheep and goats) or may use areas that are also mowed.

\section{Discussing with stakeholders}

In order to discuss the first outputs of the modelling process with the local stakeholders and to get new inputs on their behaviour related to shrub encroachment, an adapted model was developed jointly by the researchers and the Biosphere Reserve manager (Gourmelon et al., 2008) as a support tool to a role-playing game (RPG). 8 types of stakeholders were involved in the RPG sessions in order to cover the main activities and social status of the island. An ethnological survey of the impact of these sessions on stakeholders' perception demonstrated the model's capacity to raise stakeholders' awareness of the shrub encroachment process, and to stimulate discussions on reasons for and solutions to this problem. The lack of means to control the process and the poor involvement of local representatives and of the Regional Park in promoting cooperative solutions were identified as the main problems that arose while using the model. Stakeholders described the researchers that developed the model as dialogue facilitators (Charles et al., 2008).

\subsection{Interactions between agents and land use changes: the case of chough population dynamics}

In our ABM, it appeared necessary to model the chough population using attributes of interacting agents.

\section{An individual-based model for chough population dynamics}

As the number of choughs was extremely low (12 pairs for a total population of 55 individuals [Kerbiriou et al., 2005]), developing an individual-based model (IBM) was required, which enabled us to consider the effects of stochastic results linked to the low number of breeding birds and the stochasticity of the environment (Judson, 1994). This type of model led to a complete description of all the individuals: gender, age and breeding status (Figure 9). These models make more accurate predictions than deterministic models, particularly when population size is low or a population trend is near equilibrium (Travis and Dytham, 1998). This model was defined using: exhaustive census of breeding pairs, fledging success (assessment based on the 1995-2005 period [Kerbiriou, 2006]) and survival (assessment based on the 1998-2005 period [Kerbiriou and Julliard, 2007]). Moreover, certain data unavailable on Ouessant, such as female fertility according to age or adult survival rates, were completed with similar data from research carried out on the Isle of Islay in Scotland for over 20 years (Reid et al., 2003). Simulation outcomes of this individual-based model showed great convergence with deterministic modelling (supplementary material $1^{1}$ ). Spatial aspects were integrated into the model, and made the link with other agents or dynamics included in the ABM.

\section{A spatially explicit individual-based model for chough population dynamics}

Spatially-explicit population modelling is open to empirical knowledge (Grimm, 1999) and connects demography with landscape (Letcher et al., 1998; Railsback and Harvey, 2002). This kind of model is especially appropriate to this species and research issue because it includes spatial data (Kerbiriou, 2006) on breeding requirements (number of sites are restricted), foraging requirements (chough is a specialist species using short grassland only), and territoriality. Moreover, omitting spatial

\footnotetext{
${ }^{1}$ http://www2.mnhn.fr/cersp/IMG/pdf/SupplementaryMaterialsEcologicalModellingSoftware.pdf
} 
heterogeneity in grassland areas, such as tourist coastal occurrence ${ }^{2}$, induces a severe bias in chough population dynamics modelling. Furthermore, as fledging success is related to other individuals living in the neighbourhood of nests, and to distance between short grassland areas and nests (Figure 11), interactions within the chough population have to be taken into account in the ABM. The connection between chough population dynamics and other agents - sheep breeders, turf collectors or tourists - is mostly made through their impact on habitat dynamics, respectively grazing/shrub encroachment, regeneration of coastal grassland after turf extraction, or tourist trampling (Kerbiriou et al., 2008). However, tourists have a direct impact, as their numbers in August affect survival rates of young (Kerbiriou et al., 2009).

Five further methods were thus added to the above-described:

- The Chough method choisirNid definitively assigned a nest to individuals old enough to reproduce, according to nest availability. Indeed, birds that were still alive at the beginning of the year $\left(t_{\mathrm{n}}\right)$ and had reproduced the previous year $\left(t_{\mathrm{n}-1}\right)$ were considered faithful to their partner and reproduction site (Reid et al., 2003; Kerbiriou et al., 2006b). Moreover, given the choice, individuals chose nests with the best possible environment, i.e. surrounding field area of short grassland ${ }^{3}$.

- The Nest method construireTerritoire assigned a territory to a pair of choughs occupying a reproduction site according to the actual habitat distribution on Ouessant and according to the space occupied by neighbouring pairs. This first method ruled the breeding birds' process for selecting a nesting cell. It was based on two rules. The first one referred to the fact that a favourable habitat cell was chosen according to its distance from the nest: the further away it was, the less likely it was chosen (Kerbiriou et al., 2006a). The second rule suggested that, when a plot was coveted by two pairs with the same probability, seniority prevailed. Thus, the pair that had occupied the nest for the greatest number of years was predominant ${ }^{4}$. When a pair failed to form a favourable habitat $\left(7,000 \mathrm{~m}^{2}\right.$ of available coastal meadow), it failed to breed $^{5}$.

- The Chough method reproduction controlled the number of chicks according to female characteristics and the territory chosen by the pair, taking into account neighbourhood and available areas of favourable habitat. Breeding success was therefore related to an average fertility rate $\left(F_{\mathrm{m}}=\right.$ 1.6), weighted by age of the female (Reid et al., 2003) and affected by territory quality (relationship between fledging success and favourable habitat area located within a radius of $300 \mathrm{~m}$ from the nest [Kerbiriou et al., 2006a]). The number of individuals produced per a pair was however restricted to 4 chicks (Kerbiriou et al., 2006b).

- The Chough method die updated mortality, at the end of the year. Individuals disappeared randomly taking into account survival rates according to age class. Moreover, the survival rate of $1^{\text {st }}$ year birds was correlated with the number of tourists in August (supplementary material $2^{6}$ and Kerbiriou et al., 2009).

- The Chough method aging updated the age of survivors together with combined parameters, such as survival rate and female fertility, at the end of the year.

The comparison of predicted territories modelling and observed territories was good (supplementary material $3^{3}$ and Kerbiriou et al., 2007).

$A B M$ as a tool for evaluating PNRA management impact on chough population

Among the two organisations (CEMO and PNRA) involved in biodiversity conservation particularly through landscape management, simulations were used to assess the possible impact of the Regional Park's management practices on the chough population, chosen as the biodiversity indicator in our

\footnotetext{
${ }^{2}$ For example 100,000 tourists visit the western tip of the island, whereas some south-eastern coastal areas are only visited by less than 300 tourists (Kerbiriou et al., 2008).

${ }^{3}$ This intuitive rule was not based on observations.

${ }^{4}$ This rule was essentially based on preconception. However, it was not contradicted by the available fragmentary life history data on Ouessant.

${ }^{5}$ This rule was established following field observations.

${ }^{6} \mathrm{http}$ ://www2.mnhn.fr/cersp/IMG/pdf/SupplementaryMaterialsEcologicalModellingSoftware.pdf
} 
ABM. We modelled two scenarios running over a 30-year period, where PNRA management was kept separate from the other processes, for the sake of clarity. In each scenario, tourist visitation was thus considered steady with the year 2002 as a reference state; the evolution of habitats was stopped (no shrub encroachment, no erosion, no path making) as well as that of breeding. A first scenario simulated no management (scenario A), and a second scenario, current management (scenario B) (mowing of the priority zones identified by PNRA). In scenario B, the managed zones ( $34 \mathrm{ha}$ ) were immediately considered favourable habitats for choughs.

Scenario A predicted a slow decrease in the chough population until numbers reached approximately 30 individuals (Figure 10). According to scenario B, the population remained more or less as it is today. By isolating management activities of the Regional Park, we were able to clearly establish their positive impact on the chough population. The model could then be used to test other management scenarios including natural and social dynamics.

\subsection{Indicators: an original economic approach}

Traditionally, economics (a discipline use to modelling individual behaviours) considers that the key criterion used by agents to make a decision is price, which is therefore often regarded as one of the agents' "attributes". In the Ouessant model, none of the agents made their choices on the basis of this indicator. Indeed, field studies have shown that the price indicator is not used by agents in livestock management strategies or turf collecting. Nonetheless, other economic indicators related to quantity are used: cattle size according to meat demand of local inhabitants and turf collection according to restaurant demand. In these two cases, prices are considered as fixed and the demand function is linearly linked to population level for the former, and to the number of tourists for the latter. This situation is similar to situations observed in most Biosphere Reserves taking part in the project.

Other indicators therefore had to be identified on the basis of field knowledge and semi-directive interviews with the local stakeholders, as well as anthropology surveys on sheep breeding, turf collecting practices, shrub encroachment perception by holiday residents and tourist visitation (Bellec, 2005; Gourié, 2004; Joets, 2005). This mix of scientific and lay knowledge was discussed by analysing researchers' views on their relevance (Levrel et al., 2009a). Identified indicators were mostly spatial but were extremely heterogeneous (Table 4). They were classified into three categories referring to the agents' attributes: 1) strictly decision-related indicators corresponding to the agents' objectives and the decision criteria they used to achieve these objectives; 2) social interaction indicators that involved a co-evolution of the decision indicators; 3) indicators related to adaptive social behaviours. For a better understanding as to how these indicators were used in the model, we describe in detail the example of the cattle breeder below.

\section{Cattle breeder example}

Practices of interest included cattle grazing, cattle distribution on the territory and mowing practices. A certain number of key cattle breeding indicators were therefore used to define these practices:

- $\quad$ Field area and distribution of mowed plots $=$ field area and distribution of grazed plots $=$ $f$ (number of cows, cow distribution)

The number of mowed hectares corresponded precisely to the pasture areas to be used by the cows. The key indicators to evaluate both mowing and grazing activities were thus the number of cows, and their distribution on the island. This gave a spatial representation of the areas maintained by the herd. Yet, the number of cows and their distribution also varied according to two other indicators:

- Number of cows $=f$ (meat demand, access)

- $\quad$ Cow distribution $=f$ (access)

The demand indicator corresponded to the demand for Ouessant beef on the island. It only applied to Ouessant inhabitants, favouring meat from a known origin.

Therefore, even though no slaughterhouse exists on the island and cow carcasses are processed on the mainland, the meat gets back to the island and is only consumed by Ouessant inhabitants, who consider this meat as "local production" since the cattle are raised on the isle.

In this example, the price per kilogram of meat is fixed (and therefore not explicitly taken into account in the model). The level of demand is linked to the island population trends according to the results of 
our surveys. In addition, we can note that the cattle breeder gets no subsidies for this activity because it is not his main source of income.

Animal access to the pastures is an additional constraint for the breeder. Potentially, he can clear areas for his cows because he has the appropriate equipment. However, as previously pointed out, real estate is an actual issue on the island related to several access indicators.

- Access to plots $=$ rights of use $=f$ (agricultural land, size of potential plots, vegetation type, existing rights of use, type of livestock farm, roads, conflicts)

The farmer's access to the plots is above all related to those listed as reserved in priority for farming and that can easily be used. Land shortage however exists, and plots are small and scattered over the island. If the plots are too small, too much time is wasted in moving the animals around. Vegetation is another factor taken into account by the farmer. Indeed, he cannot clear plots bearing sloe trees (the final phase of shrub encroachment). He cannot use plots with existing rights of use for sheep, goats and/or horses. He gets last choice because of his unpopular status on the island. Moreover, his chosen plots are always located near a road because he needs to get to his fields easily, so that he can move his animals or bring in extra food. Lastly, increasing the size of his herd increases the risk of conflict. Conflicts therefore appear to be a new key indicator to understand the access issue and ultimately the evolution possibilities of cattle breeding on the island.

- Conflicts $=f$ (proximity to houses, perception of cows by the islanders, conservation sites) Conflicts are first of all related to the herd being in proximity of houses. If the cows are placed too close to houses, people complain of mosquitoes (horseflies) and of the place looking "dirty". This however highly depends on the perception of the herd. To some people, cows help in reducing shrubs and are well accepted, but others do not share this view. Finally, PNRA managers refuse to allow cows on conservation sites although sheep have the right to use them. According to the PNRA, the natural environment is damaged due to cow trampling. When a conflict occurs in connection with the cattle farm, the breeder is forced to move his animals, given his unpopular status. Consequently, sustainability of the cattle farm appears as a major issue:

- Sustainability of cattle farm $=f$ (conflicts, meat demand)

The sustainability of the farm is related to the fact that the current breeder is fairly old and will probably sell his flocks within the next few years. This may take place if there is still demand for Ouessant beef but also, and especially, if the conflicts connected with this activity are not too serious. Indeed, the fact that the current breeder has been able to pursue his activity, as described previously, is due to the fact that he has a core position on the island. Yet what would happen in the case of a younger farmer taking over the business? If the conflicts are too much of a problem, it is likely the current breeder will not be able to sell his herd and shrub regulating by the cows will no longer be perpetuated.

As a result of this list of indicators, the cattle breeder uses approximately 15 indicators to make his land use decisions in the model. Most of them refer to spatial indicators. A few representations are shown in figure 12.

\section{Conclusion}

The originality of the Ouessant agent-based model results largely from the co-construction process applied and its capacity to bring together lay information and scientific knowledge from different disciplines and varied viewpoints. The co-constructed conceptual model was obviously a simplified representation of the Ouessant socio-ecological system but the stakeholders involved in its conception, validation or use described it as relevant in terms of its key variables and their interrelations (Gourmelon et al., 2008). Another key issue from sharing ideas with the local stakeholders was the choice of a realistic representation of the island, which increased the feeling that the model corresponded to the micro-society of Ouessant as a whole, somewhat like in video games (e.g., the Sims). In these games, once the instructions are given at the beginning, the characters evolve independently in an environment that changes and raises the player's curiosity. In our simulation model, accuracy and completeness prevailed over the recreational aspect, and stakeholders were able to have concrete prospects for their territory and envision probable consequences of their actual behaviour in different aspects of their socio-ecological system. Further creativity options were given to 
local stakeholders during the role-playing game sessions, designed to increase the Ouessant population's awareness of the changing landscape issue (Gourmelon et al., 2008). However, the other side of the coin is also related to the weakness induced by such a level of realism, which could be the moral of the tale of the sheep, turf and bikes: stakeholders complained of the model's lack of direct playability, due to both its non user-friendly plotter interface and slow reactivity time (initialisation time is about 20 minutes). This drawback is undeniably a hindrance to the transfer of this powerful tool to the Regional Park managers, or to helping local stakeholders consider possible futures for their island. In order to partly solve this problem, we prepared a set of activities including scenarios proposed by the interdisciplinary research team and requested by stakeholders. In addition, we may develop an adapted role-playing game designed by the ABM co-modelling network and playable with a wide range of actors visiting the Oceanopolis museum in Brest. This role-playing game will multiply the discussions with varied stakeholders, and provide new inputs to the ABM model or generate a new set of scenarios. This is part of the current and future research to be carried out by inviting teachers and community education workers to the team.

\section{Acknowledgements}

This study was carried out within the framework of a project on "Organisation of access to resources and biodiversity applied to the French Biosphere Reserves", funded by the French Institute for Biodiversity.

\section{References}

Athanasiadis, I.N., Milis, M., Mitkas, P.A., Michaelides, S.C., 2009. A multi-agent system for meteorological radar data management and decision support. Environmental Modelling \& Software 24(11), 1264-1273

Bellec, S., 2005. Pratiques et représentations de la friche des résidents secondaires sur l'île d'Ouessant. Rapport, Master d'Ethnologie, Université de Bretagne Occidentale, Brest.

Bithell, M., Brasington, J., 2009. Coupling agent-based models of subsistence farming with individual-based forest models and dynamic models of water distribution. Environmental Modelling \& Software 24(2), 173-190.

Bousquet, F., Bakam, I., Proton, H., Le Page, C., 1998. Cormas: Common-pool Resources and MultiAgent Systems. Lecture Notes in Artificial Intelligence 1416, 826-838.

Charles M., Chlous-Ducharme F., Faugère E., Wintz M., 2008. Science et démocratie dans la gestion de la nature: des ethno-sociologues pris dans la modélisation d'accompagnement. Vertigo, 8 (2), http://vertigo.revues.org/index4999.html

Collectif ComMod, 2006. Modélisation d'accompagnement. In: Amblard, F., Phan, D., (Eds), Modélisation et simulation multi-agents pour les sciences de l'homme et de la société. Lavoisier, Paris, 241-252.

Di Castri, F, Balaji, V. (Eds.), 2002. Tourism, Biodiversity and Information, Backhuys Publishers, The Netherlands, $501 \mathrm{p}$.

Diáz, M., Campos, P., Pulido, F.J, 1997. The Spanish dehesas: a diversity in land-use and wildlife. In: Pain, D.J., Pienkowski, M.W. (Eds.), Farming and Birds in Europe: The Common Agricultural Policy and its Implications for Bird Conservation. Academic Press, London, pp. 331-357.

Etienne, M., Le Page, C. and Cohen, M., 2003. A Step-by-step approach to building land management scenarios based on multiple viewpoints on multi-agent system simulations. Journal of Artificial Societies and Social Simulation 6(2). 
Etienne, M., 2006. Companion modelling: a tool for dialog and concertation in biosphere reserves. Biodiversity and stakeholders: concertation itineraries. UNESCO-MAB, Biosphere Reserves, Technical notes 1, 44-52.

Etienne, M., 2009. Co-construction d'un modèle d'accompagnement selon la méthode ARDI : guide méthodologique

Ferber, J., 1995. Les systèmes multi-agents : vers une intelligence collective. InterEditions, Paris.

Franco, A.M.A. and Sutherland, W.J., 2004. Modelling the foraging habitat selection of lesser kestrels: conservation implications of European agricultural policies. Biological Conservation 120, 6374.

Fuller, R.J., Gregory, R.D., Gibbons, D.W., Marchant, J.H., Wilson, J.D., Baillie, S.R., Carter, N., 1995. Population declines and range contractions among lowland farmland birds in Britain. Conservation Biology 9, 1425-1441.

Gourié, E., 2004. Contribution à l'étude de l'occupation de l'espace Ouessantin par les moutons. Rapport, Maîtrise de géographie, Université de Bretagne Occidentale, Brest.

Gourmelon F., Bioret F., Brigand L., 1995. SIG et usage des sols : l'île d'Ouessant de 1952 à 1992. Mappemonde 4, 6-10.

Gourmelon, F., Bioret, F., Le Berre, I., 2001. Historic land use changes and implications for management of a small protected island. Journal of Coastal Conservation 7, 41-48.

Gourmelon, F., 2003. La contribution des SIG à la connaissance et à la gestion de l'environnement littoral, Habilitation à diriger des recherches, géographie, Volume $3:$ synthèse. Université de Bretagne Occidentale, Brest.

Gourmelon, F., Etienne, M., Rouan, M., Kerbiriou, C., Charles, M., Bioret, F., Chlous-Ducharme, F., Guermeur, Y., Levrel, H., 2008. Eléments de prospective environnementale dans une réserve de biosphère. CyberGeo: European Journal of Geography, article 429. [http://www.cybergeo.eu/index20343.html]

Grimm, V., 1999. Ten years of individual-based modelling in ecology: what have we learned and what could we learn in the future? Ecological Modelling 115, 129-148.

Grossi, J.L., Chenavier, L., Delcros, P., Brun, J.J., 1995. Effects of landscape structure on vegetation and some animal groups after agriculture abandonment. Landscape and Urban Planning 31, 291-301.

INSEE 2008 [http://www.insee.fr]

Joets, A., 2005. Le ramassage des mottes à Ouessant : Enjeux et valorisation d'un patrimoine culturel et naturel. Master « Culture et société », Université de Bretagne Occidentale, Brest.

Judson, O.P., 1994. The rise of the individual-based model in ecology. Trends in Ecology \& Evolution 9, 9-14

Kerbiriou, C., Thomas, A., Floc'h, P., Beneat, Y., Floté, D., Gager, L., Champion, M., 2005. Recensement 2002 de la population bretonne de Crave à bec rouge (Pyrrhocorax pyrrhocorax). Ornithos 12, 113-122. 
Kerbiriou, C., 2006. Impact des changements d'usage sur la viabilité d'une population menacée dans un espace multi-protégé : le Crave à bec rouge (Pyrrhocorax pyrrhocorax) sur l'île d'Ouessant. Thèse d'Ecologie, Muséum National d'Histoire Naturelle, Paris. [http://www2.mnhn.fr/cersp/spip.php?rubrique13]

Kerbiriou, C., Gourmelon, F., Jiguet, F., Le Viol, I., Bioret, F., Julliard, R., 2006a. Linking territory quality and reproductive success in the chough (Pyrrhocorax pyrrochorax): implications for conservation management of an endangered population. Ibis 148, 352-364.

Kerbiriou, C., Le Viol, I., Nisser, J., Audevard, A., Le Pennec, V., 2006b. Biologie de la reproduction du Crave à bec rouge (Pyrrhocorax pyrrhocorax) en Bretagne (France). Alauda 74, 399-412.

Kerbiriou, C., Julliard, R., 2007. Demographic consequences of prey availability and diet of Redbilled Chough (Pyrrhocorax pyrrhocorax. Bird Study, 54, 296-306.

Kerbiriou, C., Rouan, M., Levrel, H, Leviol, I., Dupont H. \& Etienne M. 2007. Use of a Multi Agent System for management planning of a rare and threatened population of bird in a multi protected area undergoing drastic land use change. 21st Annual Meeting of Society for Conservation Biology, 1-5 July 2007, Port Elizabeth, South Africa.

Kerbiriou, C., Leviol I., Jiguet, F., Julliard, R., 2008. The impact of human frequentation on coastal vegetation in a biosphere reserve. Journal of Environmental Management, 88, 715-728.

Kerbiriou, C., Le Viol, I., Robert, A., Porcher, E., Gourmelon, F., Julliard, R., 2009. Tourism in protected areas can threaten wild populations. from individual response to population viability of the chough Pyrrhocorax pyrrhocorax. Journal of Applied Ecology, 46(3), 657-665 [doi: $10.1111 / \mathrm{j} .1365-2664.2009 .01646 . x]$.

Krebs, J.R., Wilson, J.D., Bradbury, R.B., Siriwardena, G.M., 1999. The second silent spring?. Nature 400, 611-612.

Letcher, B.H., Priddy, J.A ., Walters, J.R., Crowder, L.B., 1998. An individual-based, spatiallyexplicit simulation model of the population dynamics of the endangered red-cockaded woodpecker, Picoides borealis Biological Conservation, 86: 1-14.

Levrel H., 2004. Synthèse des entretiens menés lors du projet IFB «Organisation de l'accès aux ressources et biodiversité : application aux Réserves de Biosphère françaises ». personal communication.

Levrel, H., Etienne, M., Kerbiriou, C., Le Page, C., Rouan, M., 2009a. Co-modelling process, negotiations and power relationships: some outputs from a MAB project in the island of Ouessant. Society and Natural Resources 22, 1-17.

Levrel H., Kerbiriou C., Couvet D., Weber J., 2009b. OECD pressure-state-response indicators for managing biodiversity: a realistic perspective for a French biosphere reserve. Biodiversity and Conservation, 18(7), 1719-1732 [doi: 10.1007/s10531-008-9507-0].

MacDonald, D., Crabtree, J.R., Weisinger, G., Dax, Y., Stamou, N., Fleury, P., Guttierez Lazpita, J., Gibon, A., 2000. Agricultural abandonment in mountain areas of Europe: environmental consequences and policy response. Journal of Environment Management 59, 47-69.

Maes D. \& Dyck H.V. 2001. Butterfly diversity loss in Flanders (north Belgium):Europe's worts case scenario. Biological conservation 99, 263-276. 
Minar, N., Burkhart, R., Langton, C., Askenazi, M., 1996. The Swarm simulation system: A toolkit for building multi-agent simulations. Working Paper 96-06-042, Santa Fe Institute, Santa Fe.

Moreno, N., Quintero, R., Ablan, M., Barros, R., Davila, J., Ramirez, H., Tonella, G., Acevedo, M.F., 2007. Biocomplexity of deforestation in the Caparo tropical forest reserve in Venezuela: An integrated multi-agent and cellular automata model. Environmental Modelling \& Software 22(5), 664-673.

Railsback S.F. \& Harvey, B. 2002. Analysis of habitat-selection rules using an individual-based model. Ecology 83, 1817-1830.

Rattier, S., 2005. Evaluation de la contribution de la vaine pâture à l'entretien des milieux de l'île d'Ouessant. Mémoire ingénieur, ENSAIA, Nancy.

Reid, J.M., Bignal, E.M., Bignal, S., McCracken, D.I., Monaghan, P., 2003. Environmental variability, life-history co-variation and cohort effects in the red-billed chough Pyrrhocorax pyrrhocorax. Journal of Animal Ecology 72 36-46.

Siriwardena, G.M., Baillie, S.R., Buckland, S.T., Fewster, R.M., Marchant, J.H., Wilson, J.D., 1998. Trends in the abundance of farmland birds: a quantitative comparison of smoothed common birds census indices. Journal of Applied Ecology 35, 24-43.

Tilman, D., Fargione, J., Wolff, B., D_Antonio, C., Dobson, A., Howarth, R., Schindler, D., Schlesinger, W.H., Simberloff, D., Swackhamer, D., 2001. Forecasting agriculturally driven global environmental change. Science 292, 281-284.

Travis, J.M.J., Dytham, C., 1998. The evolution of dispersal in a metapopulation: a spatially explicit, individual-based model. Proceedings of the Royal Society B: Biological Sciences, 265, 17-23. 


\section{Legends of tables and figures}

Table 1: Cell class attributes for the Ouessant model

Table 2: time step of the Ouessant model

Table 3: Simulation parameters of the "current trend" scenario

Table 4: Decision and social interaction indicators for the agents represented in the model

Figure 1: Progression of pasture and land fallow in relation to sheep flock size, outcome prediction of first modeling approach

Figure 2: modelling process chronogram

Figure 3: draft of a conceptual model following the first IFB project meeting

Figure 4: final conceptual model (June 2006)

Figure 5: Vegetation dynamics model on Ouessant (state and transition diagram)

Figure 6: Loading evolution of different type of livestock farms and land use evolution on the isle of Ouessant from 1844 to the present time (after Gestin et al., 1982, Francoual, 1993, Gourié 2004, Kerbiriou 2004, Gourmelon et al. 2001)

Figure 7: Mean stability test on a sampling of 100 simulations and two samples of 30 simulations

Figure 8: Simulation results for the so-called «tendential » scenario

Figure 9: Conceptual model of a bird life cycle

Fertility : Fi $=\mathrm{Pi}$ x $\alpha \mathrm{i}$ or Pi correspond to the mean reproduction success of females aged $\mathrm{i}$ and $\alpha \mathrm{i}$ to the primary sex ratio $(\alpha i=0,5)$.

Survival : Si corresponds to the survival probability between the ages $i$ and $i+1$

Figure 10: Mean size of populations for existing paths in relation with scenarios A $(\bullet)$ and B (o) ; IIterations $=100 ; \mathrm{N}_{0}=55 ;$ age structure at onset corresponds to the matrix steady state age. It is identical for all simulations and scenarios].

Figure 11: Distribution of the distance between nest and foraging areas for the chough.

Figure 12: Spatial indicators used by the cattle breeder to make his use decisions. 
Table 1: Cell class attributes for the Ouessant model

\begin{tabular}{|l|l|l|}
\hline \multicolumn{1}{|c|}{ attribute name } & \multicolumn{1}{c|}{ Description } & \multicolumn{1}{c|}{ origin } \\
\hline age & age of vegetation & random at initialization \\
\hline typeVeg & the most representative type of vegetation & GIS, Gourmelon \\
\hline typePat & type of pasture & GIS, Gourié, Kerbiriou, Rouan \\
\hline chemin & type of path crossing the cell & GIS, Kerbiriou \\
\hline maison & presence of a house within the cell & GIS, BDTopo IGN \\
\hline dateEtrepage & date at which the cell was last turf collected & calculated during simulation \\
\hline droitUsage & number and cell type of livestock farmer & calculated during simulation \\
\hline nid & presence of a chough's nest in the cell & GIS, Kerbiriou \\
\hline appartenanceNid & nest number (chough couple) cell « owner » & calculated during simulation \\
\hline siteClasse & type of listed zone MAB & GIS, BR atlas \\
\hline Interdiction & cell access forbidden by CEMO & calculated during simulation \\
\hline zoneFixe & cell reserved for a given type of livestock farming & GIS, Levrel, Rouan \\
\hline zoneLibre & cell reserved for potential livestock farming & GIS, Levrel, Rouan \\
\hline fauchePNRA & cell currently mowed by PNRA & GIS, Kerbiriou \\
\hline zoneTouriste & belonging to a tourist zone & GIS, Kerbiriou \\
\hline pelouseRase & type of short grass & GIS, Kerbiriou \\
\hline accessibiliteVoiture & access availability for the turf collectors & GIS, Joets, Rouan \\
\hline typeVegInit & vegetation type at simulation initialization & calculated upon simulation \\
\hline parking & presence of a car park for tourists & GIS, Bioret, Kerbiriou \\
\hline couvertSolNu & percent of bare soil & initialization + GIS, Kerbiriou \\
\hline
\end{tabular}

Table 2: time step of the Ouessant model

\begin{tabular}{|l|l|l|l|}
\hline Activities & February to May & June to September & October to January \\
\hline Livestock farming & Stick grazing ${ }^{2}$ & Stick grazing & Common range grazing \\
\hline Chough & Construction of territory & Reproduction & Free feeding \\
\hline Tourism & Low season & High season & Low season \\
\hline
\end{tabular}

Table 3: Simulation parameters of the "current trend" scenario

\begin{tabular}{|r|c|}
\hline Parameter wording & Parameter value \\
\hline NbCrave & 55 \\
\hline nbEleveursChevre & 45 \\
\hline nbEleveursMouton & 155 \\
\hline InitEleveurVache & 1 \\
\hline InitEleveurCheval & 1 \\
\hline nbEtrepeurs & 5 \\
\hline NbNids & 17 \\
\hline nbResidents & 380 \\
\hline nbRestaurateurs & 5 \\
\hline Visiteur : InitEffectif & 130000 \\
\hline
\end{tabular}

\footnotetext{
${ }^{1}$ This attribute was calculated in relation to the percentage of bare soil observed on the island in relation with the concerned meadow characteristics (depth of soil, trampled or not) and according to a forced random rating

${ }^{2}$ Part of the year, sheep owners rope their sheep to a stick in order to concentrate grazing around their house.

The beginning of this period corresponds to the sheep market that is held on the first Wednesday of February.
} 
Table 4: Decision and social interaction indicators for the agents represented in the model

\begin{tabular}{|c|c|c|}
\hline Agents & Decision indicators & Social interaction indicators \\
\hline Sheep breeders & $\begin{array}{l}\text { Number of animals (determines rights of use in } \\
\text { terms of field area) } \\
\text { Rights of use (near houses and in grazing zones) } \\
\text { Season (determines common range and stick } \\
\text { grazing periods) } \\
\text { Age (sells his flock at } 80 \text { years) }\end{array}$ & $\begin{array}{l}\text { Existing rights of use (determine } \\
\text { the rights of use that may be } \\
\text { created) }\end{array}$ \\
\hline Horse breeders & $\begin{array}{l}\text { Number of animals (determines rights of use in } \\
\text { terms of field area) } \\
\text { Rights of use (fixed and mobile) } \\
\text { Grazing zones (determines the evolution of } \\
\text { rights of use) } \\
\text { Season (horses are kept closer to the riding } \\
\text { school during the summer season) } \\
\text { Age (sells his herd after the age of } 65 \text { years) }\end{array}$ & $\begin{array}{l}\text { Existing rights of use (determines } \\
\text { the possibility of changing rights of } \\
\text { use) }\end{array}$ \\
\hline Goat breeders & $\begin{array}{l}\text { Owns sheep (by convention, only sheep } \\
\text { breeders are allowed to have goats) } \\
\text { Amount of fallow near the house (encourages } \\
\text { the breeder to acquire goats and to place them on } \\
\text { the fallow front) } \\
\text { Rights of use (rights of use linked to sheep } \\
\text { breeding and fallow land) } \\
\text { Season (goats are grouped at one extremity of } \\
\text { the island during common range grazing ) }\end{array}$ & \\
\hline Cow breeders & $\begin{array}{l}\text { Number of animals (determines the rights of use } \\
\text { in terms of field area) } \\
\text { Rights of use (fixed and mobile) } \\
\text { Grazing zone (to determine rights of use) } \\
\text { Meat demand (determines the number of cows) } \\
\text { Age (tries to sell his farm after the age of } 65 \\
\text { years) }\end{array}$ & $\begin{array}{l}\text { Conflicts with the Park and } \\
\text { residents } \\
\text { Existing rights of use (determines } \\
\text { the evolution possibilities of rights } \\
\text { of use) }\end{array}$ \\
\hline $\begin{array}{l}\text { CEMO (Regional } \\
\text { Park) }\end{array}$ & & $\begin{array}{l}\text { Presence of cows on conservation } \\
\text { sites }\end{array}$ \\
\hline Turf collectors & & Demand for turf by restaurants \\
\hline Red-billed choughs & $\begin{array}{l}\text { Nest (builds its territory from a nest) } \\
\text { Bare grassland (builds its territory from its } \\
\text { habitat) }\end{array}$ & $\begin{array}{l}\text { Age of other individuals (means a } \\
\text { more important status and a higher } \\
\text { probability of victory in the event of } \\
\text { conflicts) }\end{array}$ \\
\hline Sheep flocks & Grazing zone (guides the flocks) & \\
\hline
\end{tabular}




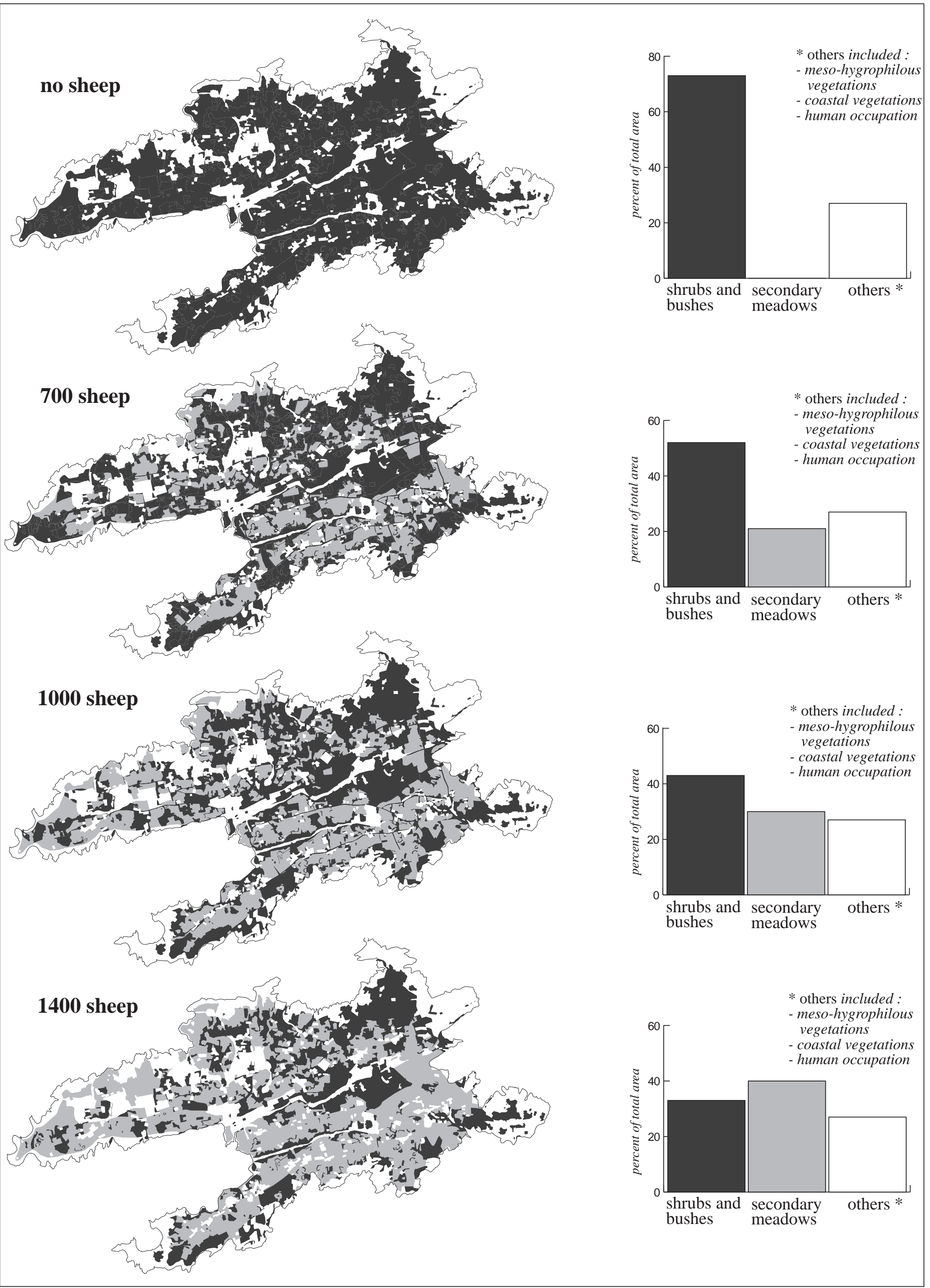


$\square$ scientists $\square$ scientists + manager $\quad \square$ scientists + trainee $\quad \square$ modeller(M. Rouan)

scientists + manager + local stakeholders

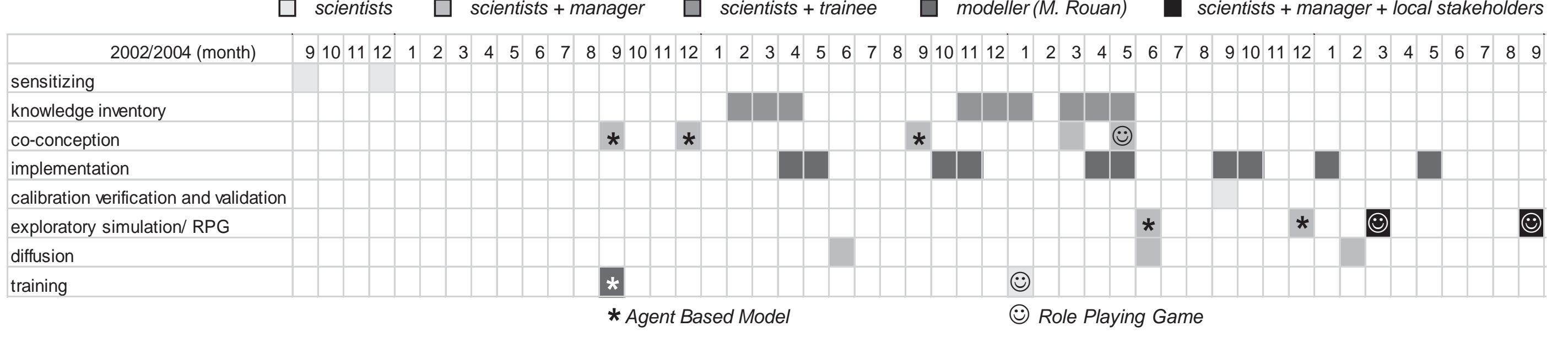




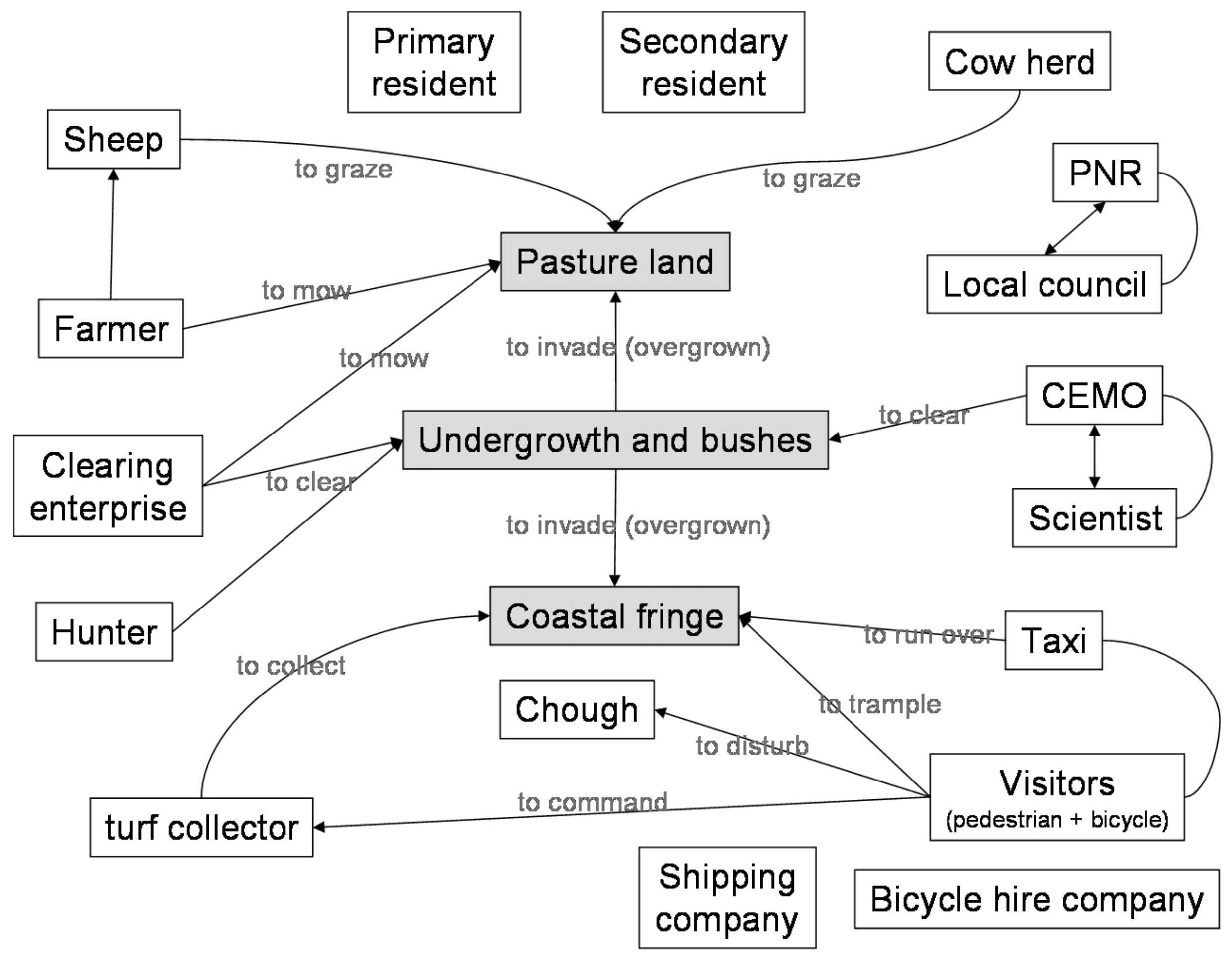




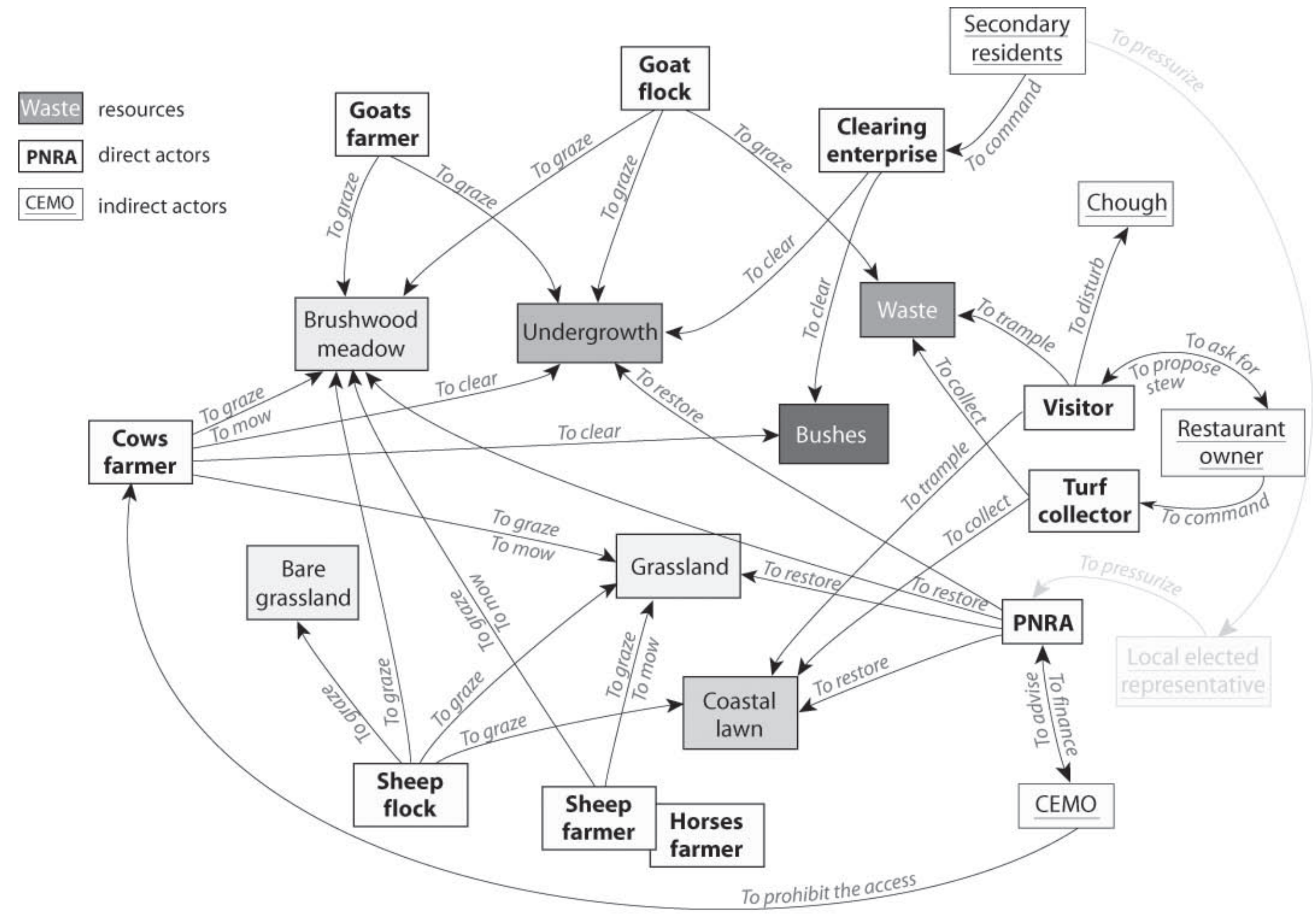




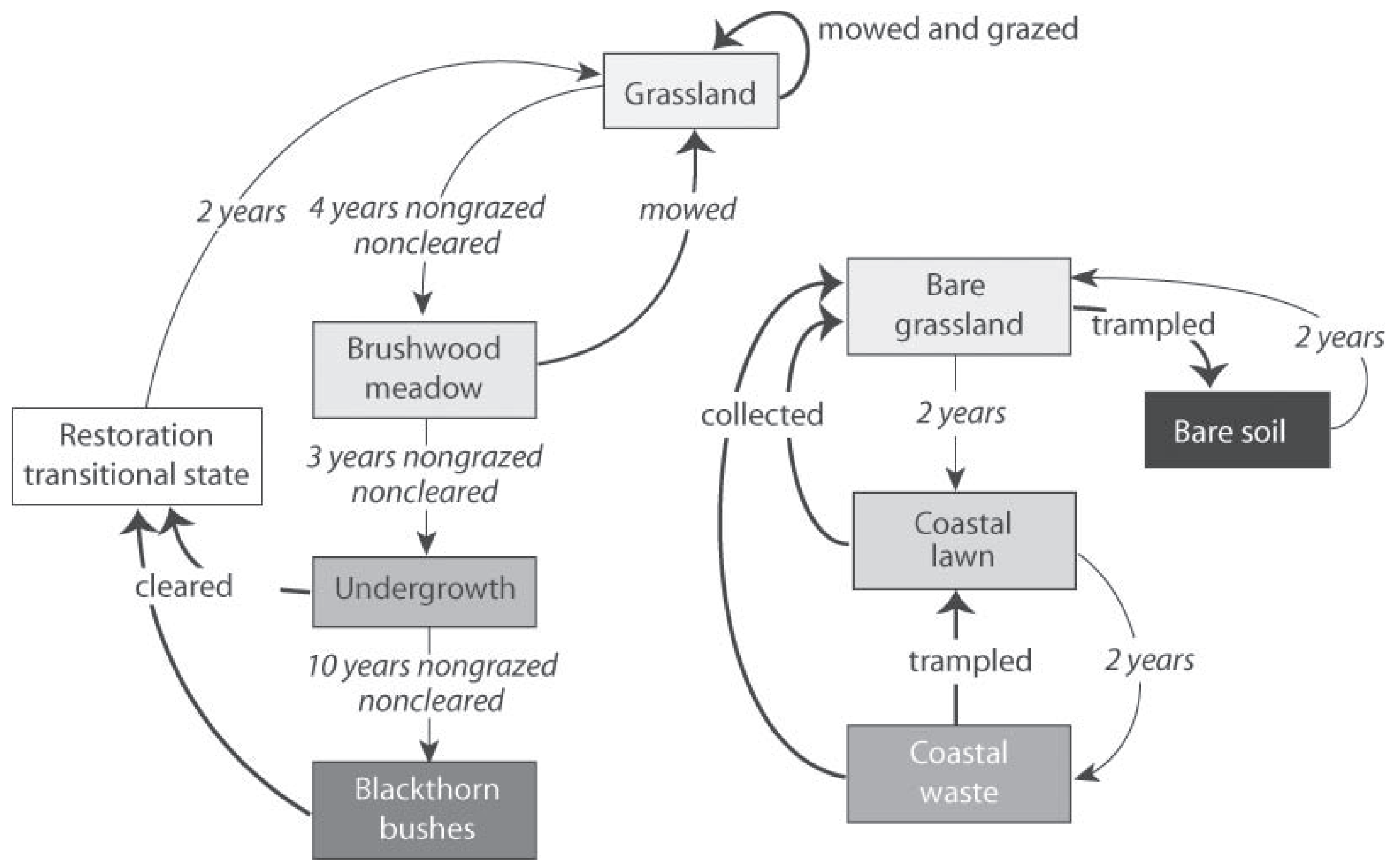




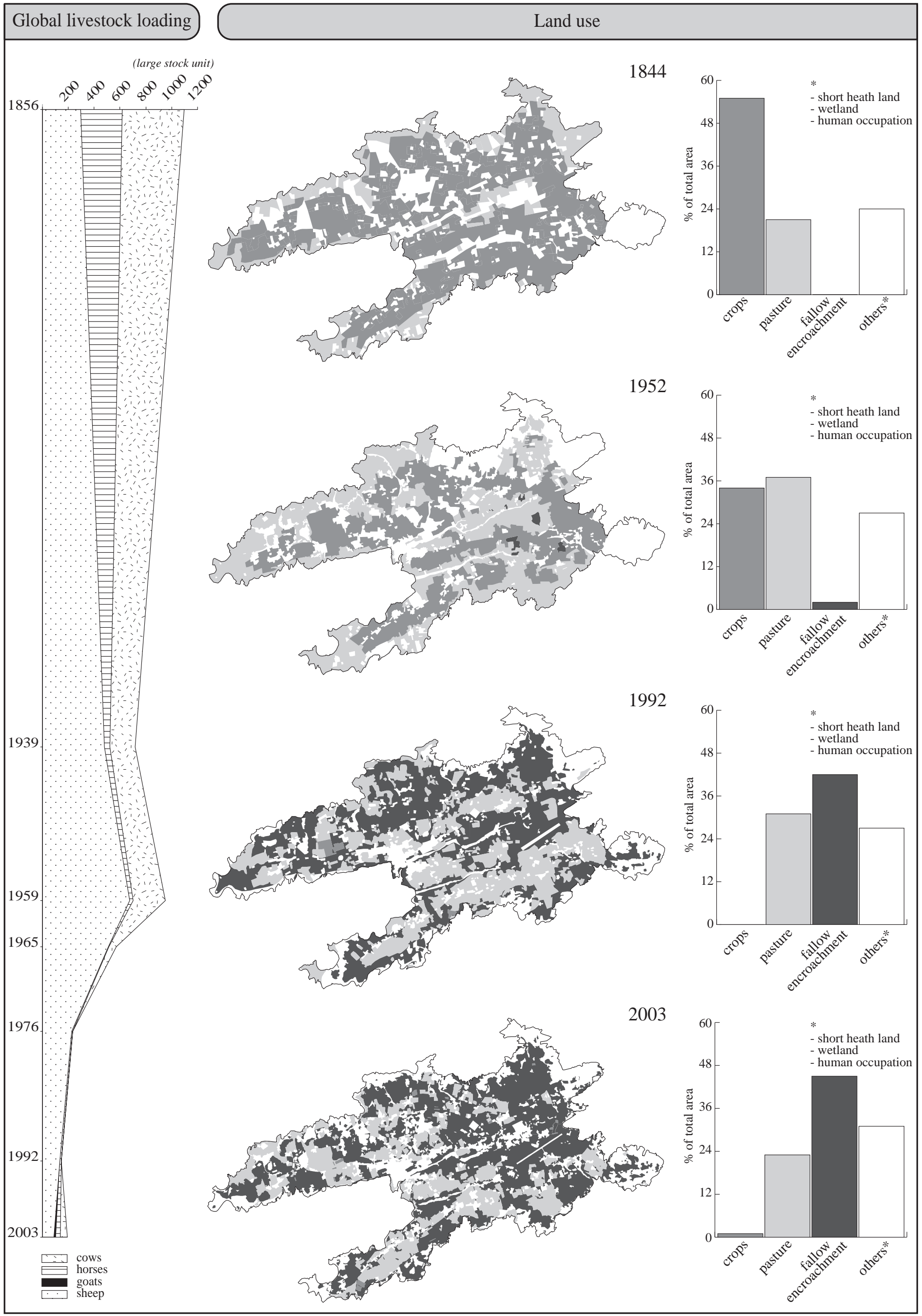




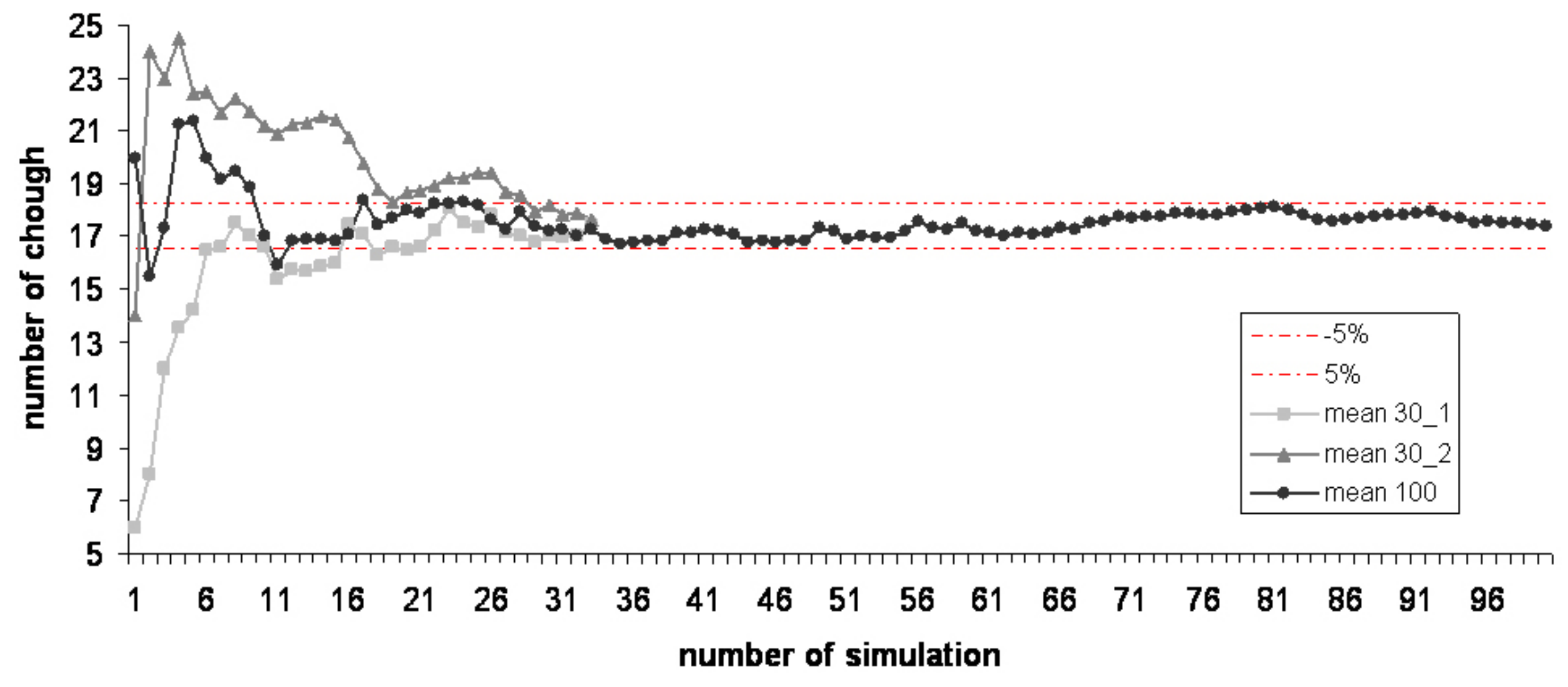



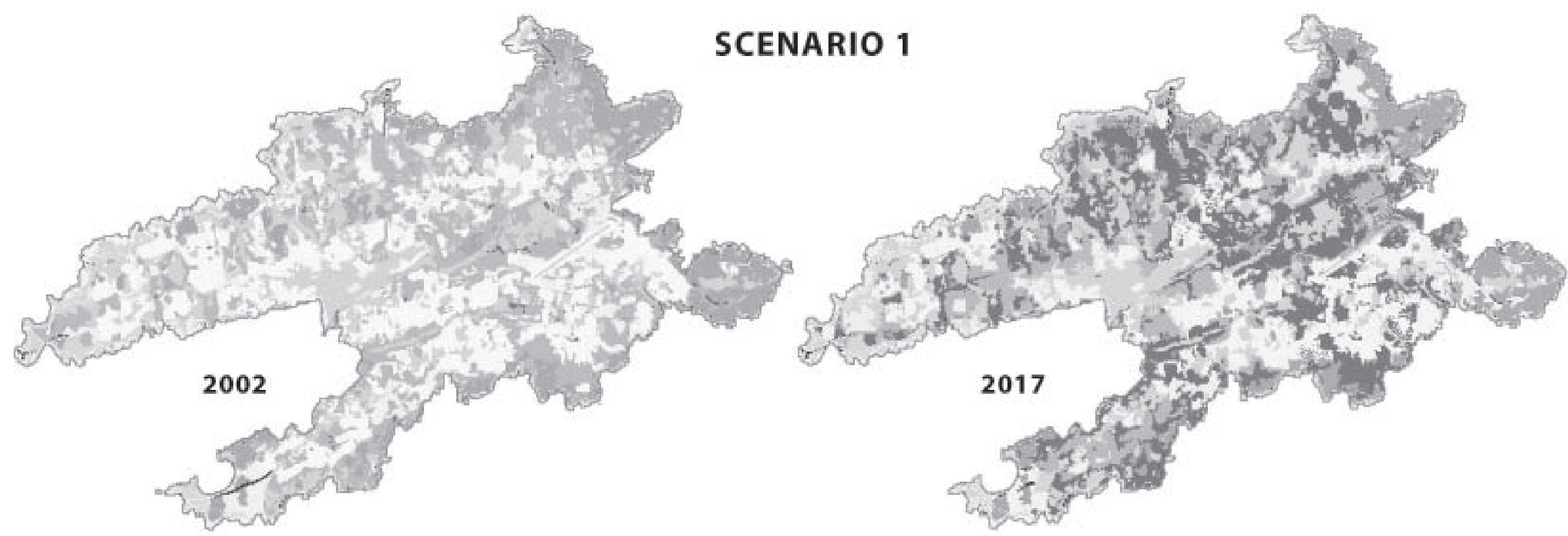

\section{Undergrowth (in ha)}

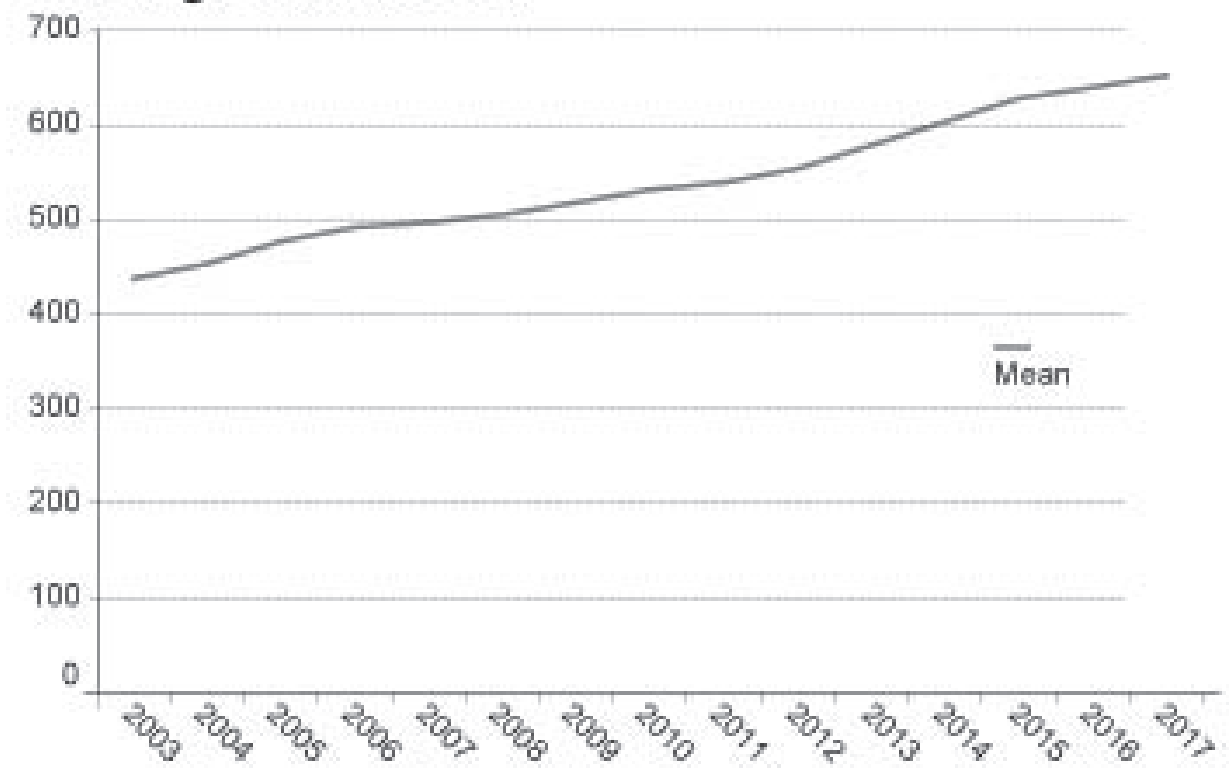

\section{Number of chough}

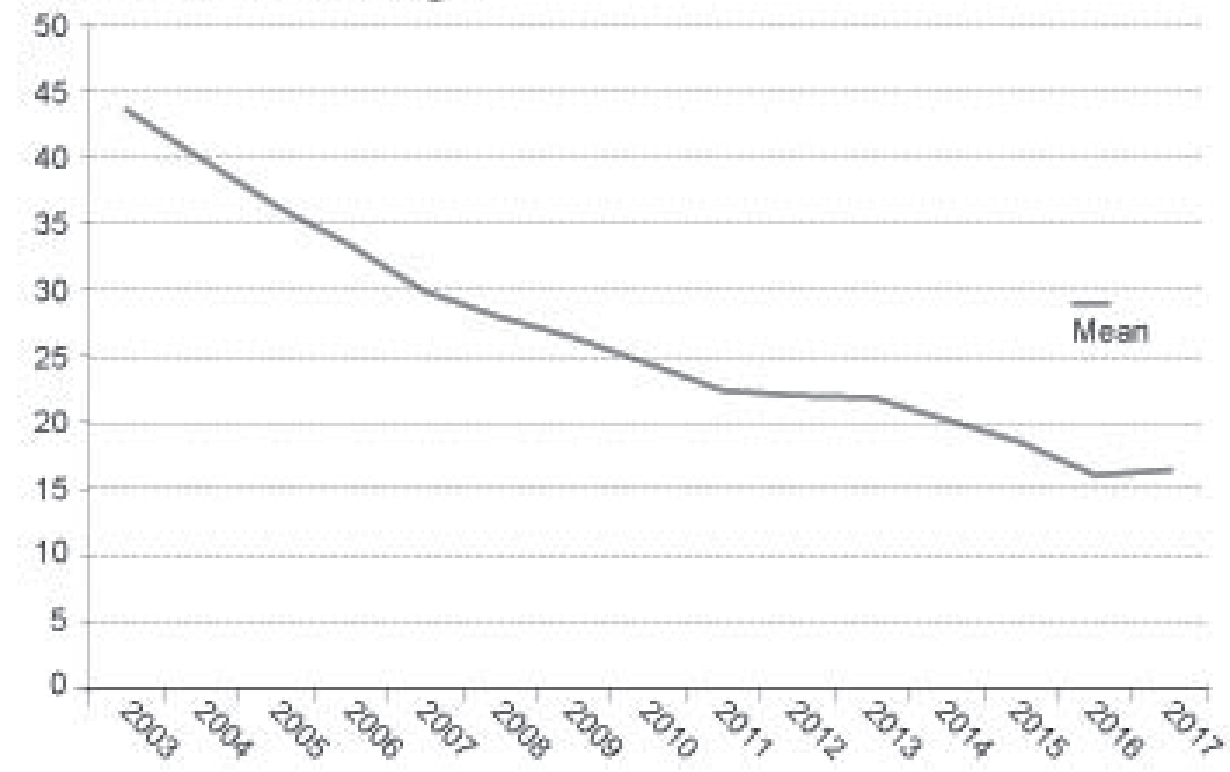




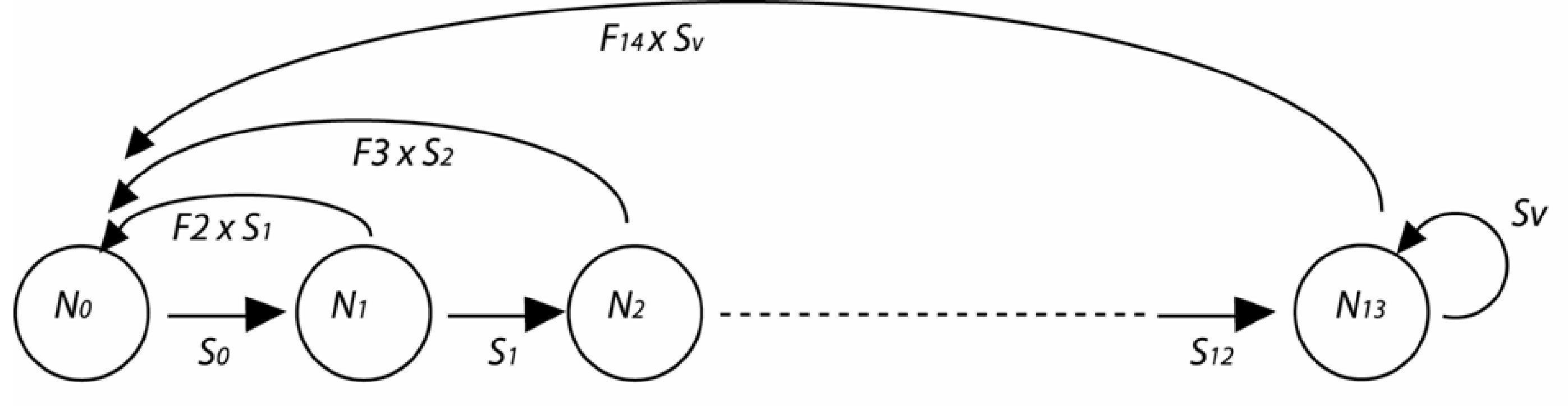




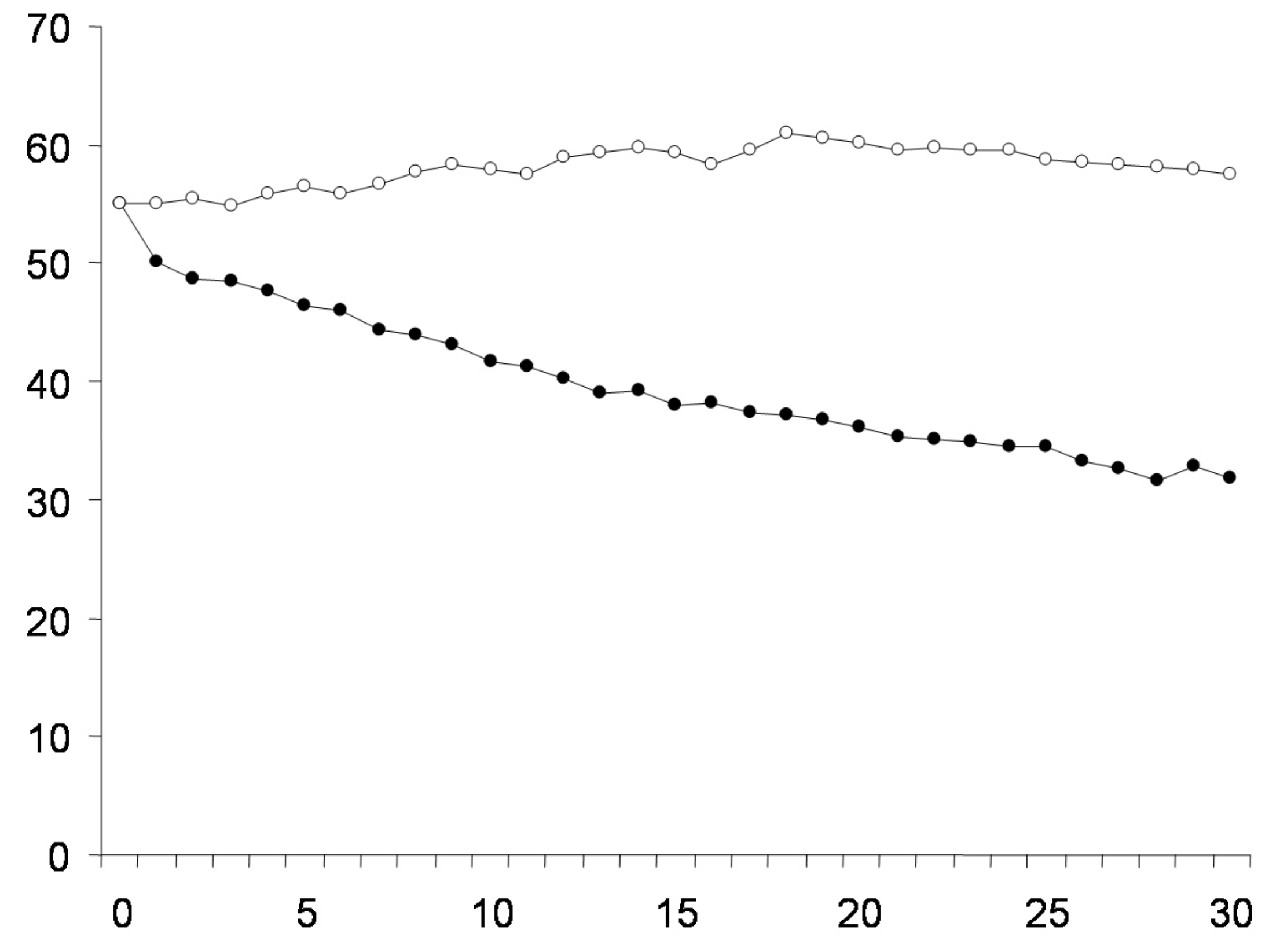




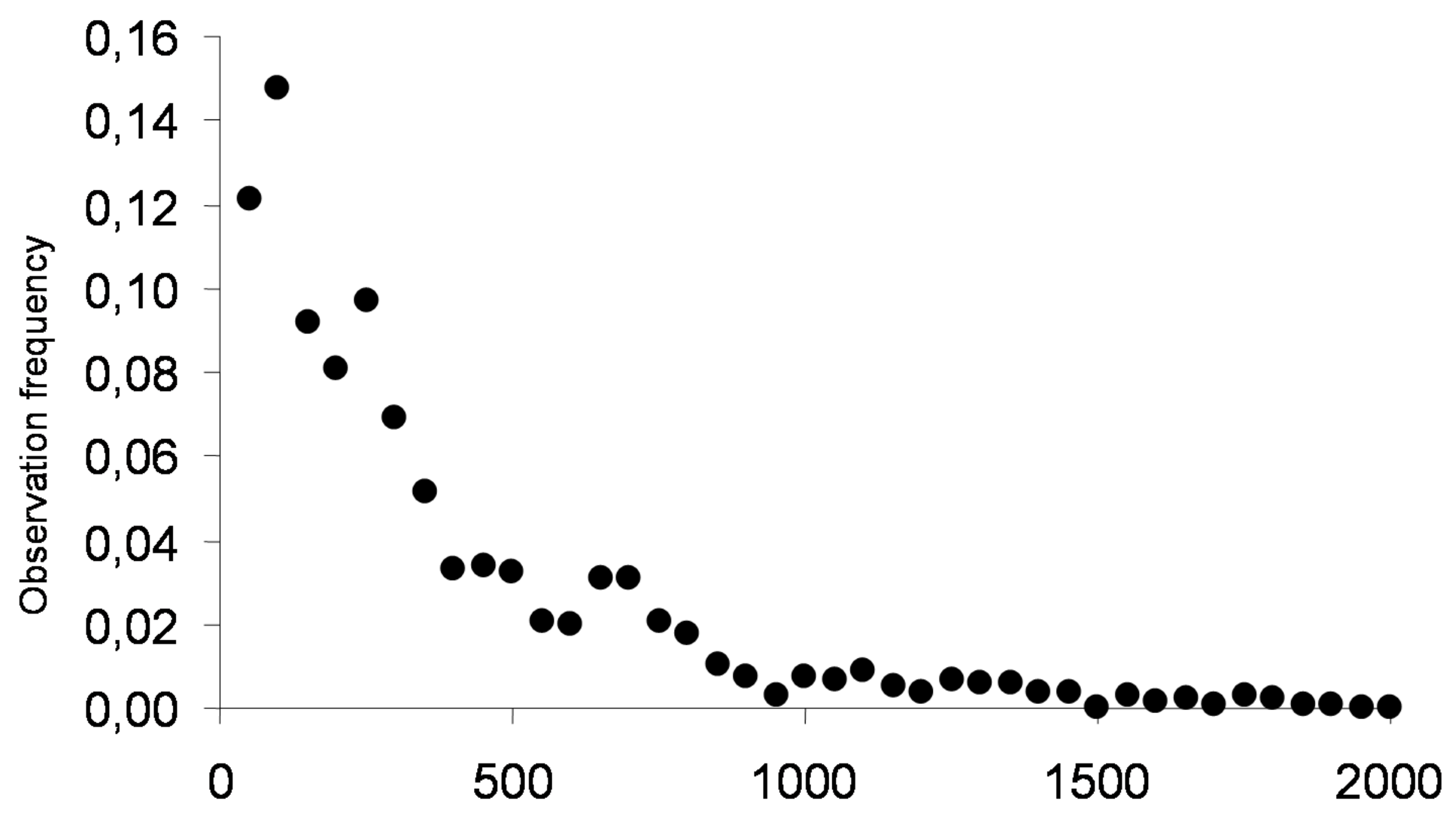

Distance from nest in meters 


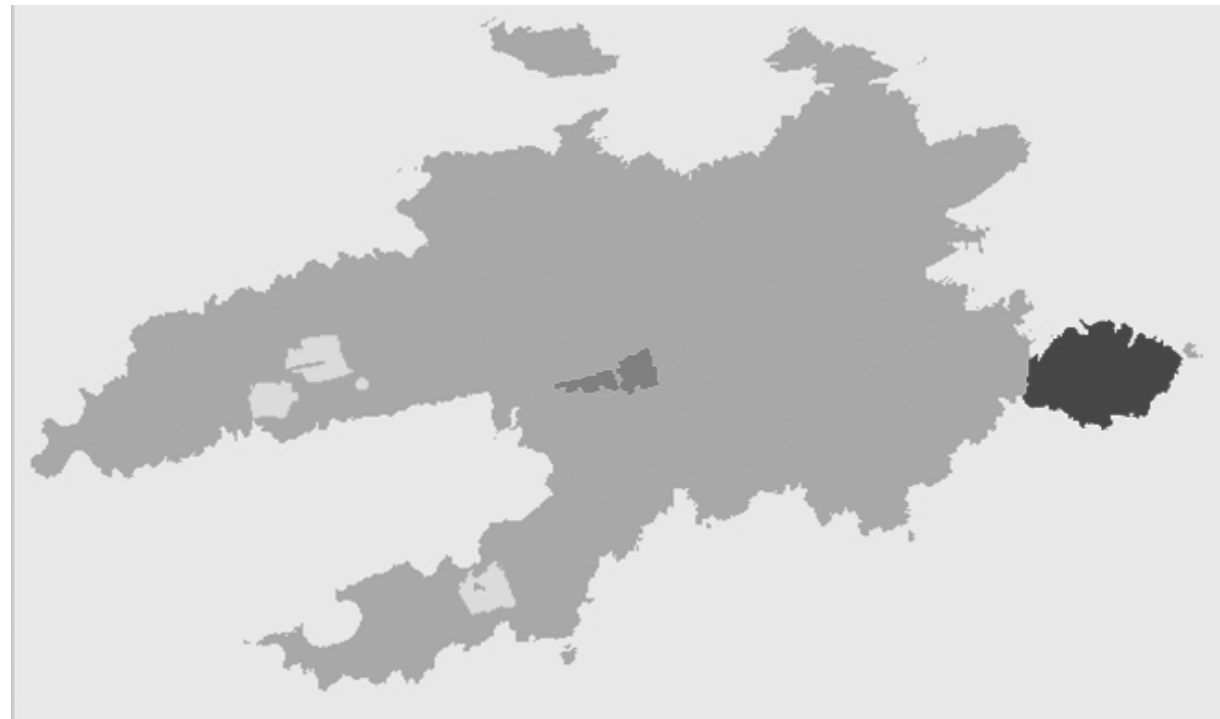

Agricultural lands, existing right of use

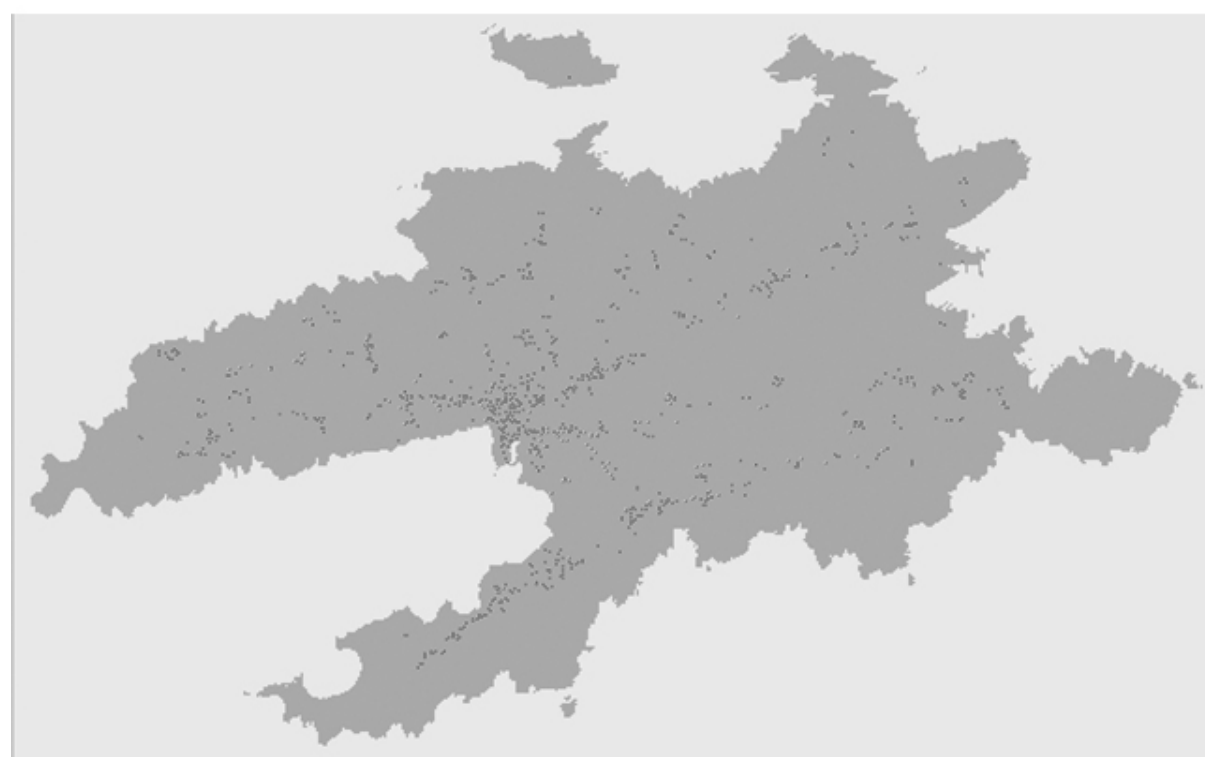

Nearness of houses, cows perception

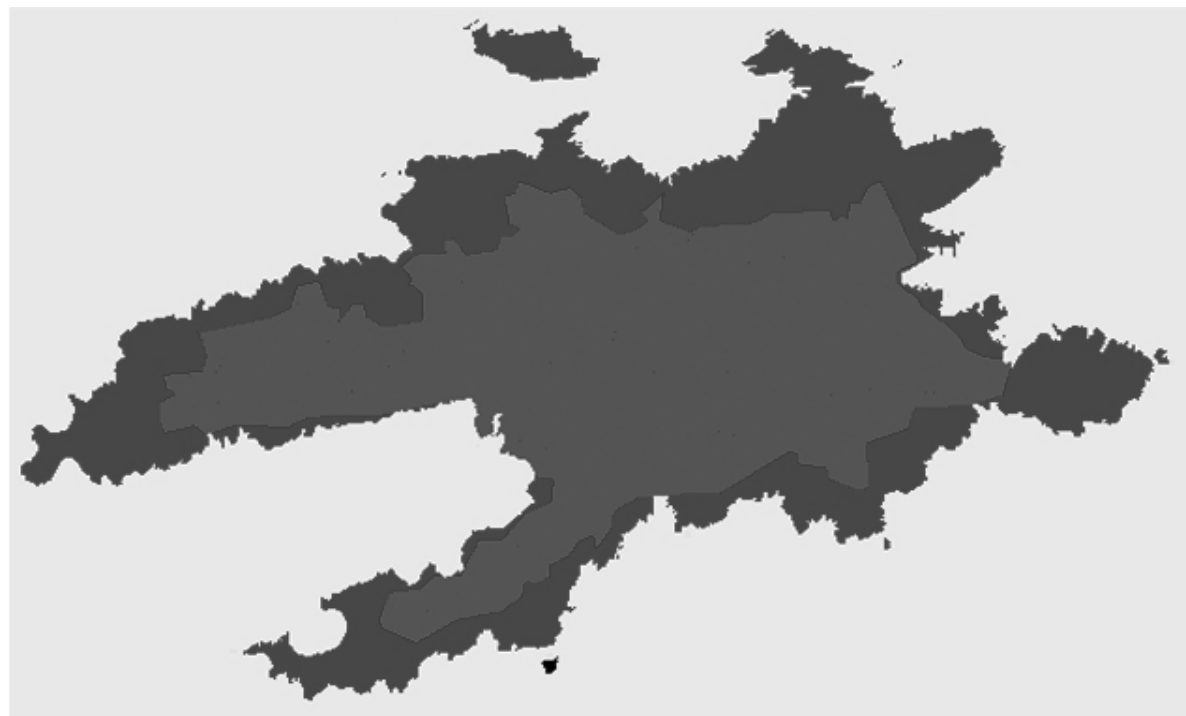

Conservation areas

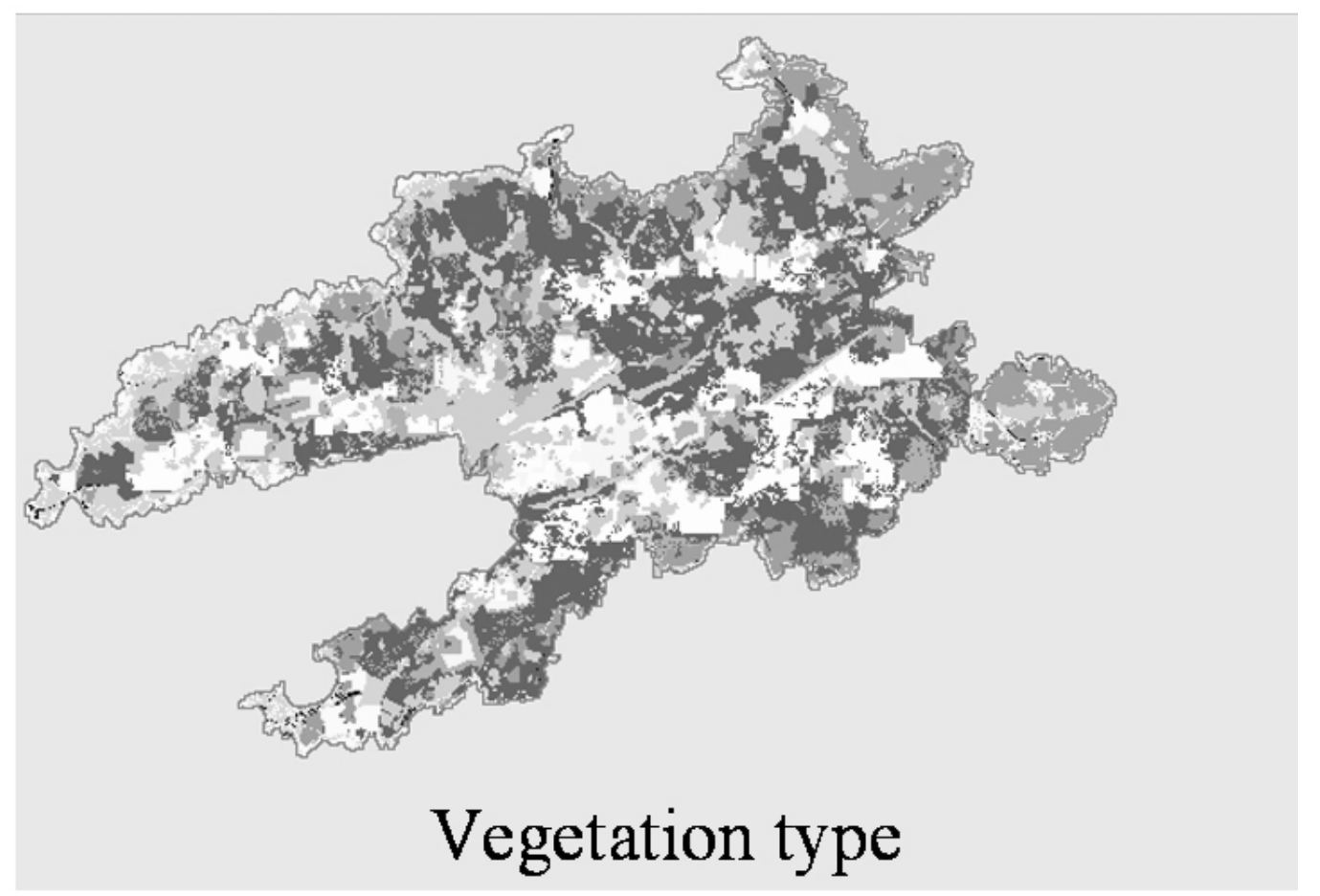

